Article

\title{
Regional Happiness and Corporate Green Innovation: A Financing Constraints Perspective
}

\author{
Dukangqi Li * and Weitao Shen
}

check for updates

Citation: Li, D.; Shen, W. Regional Happiness and Corporate Green Innovation: A Financing Constraints Perspective. Sustainability 2022, 14 , 2263. https://doi.org/10.3390/ su14042263

Academic Editor: Anna Mazzi

Received: 26 January 2022

Accepted: 14 February 2022

Published: 16 February 2022

Publisher's Note: MDPI stays neutral with regard to jurisdictional claims in published maps and institutional affiliations.

Copyright: (C) 2022 by the authors. Licensee MDPI, Basel, Switzerland. This article is an open access article distributed under the terms and conditions of the Creative Commons Attribution (CC BY) license (https:// creativecommons.org/licenses/by/ $4.0 /)$.
School of Management, Xiamen University, Xiamen 361005, China; wtshen@xmu.edu.cn

* Correspondence: lidukangqi@stu.xmu.edu.cn
Abstract: In China's period of economic transition, enterprises often find it difficult to obtain the support of formal institutions and the capital market, so informal institutions such as value and social networks are particularly important resources. Regional happiness can influence corporate green innovation by shaping the external environment. This study takes a sample of Chinese A-listed companies and empirically tests the impact of regional happiness on corporate green innovation by constructing happiness data at a city level. The empirical results show that in cities with high levels of happiness, the green innovation level of listed companies is higher. This is manifested by a higher number of green patents and green invention patent applications. To test for reliability, a series of robustness tests were carried out. First, we performed 2SLS regression using the instrumental variable method in consideration of the possibility of a reverse generation of endogenous problems. Second, we remeasured corporate green innovation using a green patent authorization considering the rationality and applicability of the measurement method of core variables, and then remeasured the regional happiness based on a text analysis of social media content. Both tests showed that the conclusions are robust. Mechanism analysis revealed that regional happiness has an impact on corporate green innovation through financing constraints, namely, that it can either alleviate enterprises' financing constraints, or substitute for regional financial development to promote corporate green innovation. Further analysis showed that, for enterprises lacking political connections, regional happiness plays a significant role in promoting green innovation. This indicates that, in the absence of financing convenience, the resource effect brought by regional happiness acts as a substitute for an implicit government guarantee. This study provides new insights into the determinants of corporate green innovation and the value of informal institutions in environmental sustainability.

Keywords: regional happiness; financing constraints; informal institutions; green innovation

\section{Introduction}

With the increasingly serious environmental problems represented by global warming, the relationship between humans and the natural environment has become one of the most important issues facing the world. Environmental pollution and ecological damage are generally attributed to the production and operational activities of enterprises [1]. Green innovation consists of new or improved products, processes, services, and management practices, and aims to reduce energy consumption and pollution. It can significantly reduce the adverse impact of commercial and industrial activity on the environment and realize added value for customers and enterprises [2]. Green innovation provides a fundamental impetus for green productivity growth and macroeconomic growth through tourism development [3]. Green innovation also generates positive externalities through knowledge spillovers, thus promoting the adoption and diffusion of environmental technologies at an industry level — both regionally and nationally [4] —and generating extensive environmental benefits [5]. Encouraging enterprises to engage in green innovation requires a series of external environment constructions, and the social environment of enterprises is an important aspect. Enterprises have both economic and social attributes, and their economic 
activities are inseparable from the social system on which they operate [6]. Due to the social embeddedness of enterprises [7], the social environment has a significant impact on the behavior of enterprises. The contemporary research perspective on the external environment and corporate green innovation is based on the formal system dominated by environmental regulation; however, no consensus has been reached on whether there exists a positive effect of environmental regulation on corporate green innovation. This indicates that the extant research may have ignored certain crucial factors that determine corporate green innovation, which need to be explored further. Regional cultural changes in the attitude and behavior of economic actors shape the external environment and influence corporate green innovation; however, studies have rarely paid attention to informal institutions, such as regional culture, when emphasizing the role of the external environment on corporate green innovation. Regional happiness is an important regional culture [8]; the influence of regional happiness on corporate financial decisions has already been established [8,9]. A cross-city study conducted by Chuluun and Graham 8 shows that cities' happiness levels promote investment behaviors of local enterprises. Heo and Hou [9] provide international evidence that happiness plays a vital role in promoting corporate innovation. Regional happiness is a positive psychological state shared by regional residents, and its improvement optimizes the external environment of enterprises. Happiness is closely related to pro-social attributes $[10,11]$, which makes people more trusting of others and willing to participate in society [12]. From an economic perspective, happiness promotes the expansion of social relationship networks and builds trust within a region [13]. Rich social networks in regions that accompany higher levels of happiness facilitate more channels for enterprises to obtain innovation resources, which helps the promotion of green innovation. Importantly, the above analysis necessitates additional discussions on whether a higher regional happiness can significantly promote corporate green innovation, while the questions of whether this effect exists and the mechanisms behind it remain unanswered in the literature. Therefore, based on the data from Chinese listed companies and the cities' happiness index, this study evaluates the influence and mechanism of regional happiness at the city level on corporate green innovation.

In China's period of economic transition, there are evident differences in social development modes among the different regions in China, and different levels of happiness evolve in different regions and cities [14]. Meanwhile, China's extensive development model of high investment, high pollution, and high consumption in recent decades has caused serious environmental pollution. China urgently needs to shift from an extensive factor input growth model to a green growth model driven by total factor productivity [15]. The Chinese government is actively promoting the concept of green development. China expects carbon dioxide emissions to peak before 2030 and aims to offset its own carbon dioxide emissions through afforestation, energy conservation, and emissions reduction to achieve zero carbon dioxide emissions by 2060 [16]. Strong asset and financial capacities are prerequisites for green innovation [17]. Compared to mature economies, it is more difficult for enterprises to obtain support from formal institutions and capital markets in this period of economic transition; therefore, informal institutions such as value cultures are particularly important in providing resources [18]. This study selects Chinese A-listed companies as samples to investigate empirically the impact of regional happiness on corporate green innovation and to highlight the important impact of informal institutions on corporate green innovation in the context of incomplete legal systems in transition economies.

Our study makes the following contribution to the existing literature. First, this study is amongst the first to include regional happiness as a social environment factor that drives green innovation into the analytical framework of the determinants of corporate green innovation. The study can supplement the literature on the influencing factors of corporate green innovation from the perspective of informal institutions, thereby opening up a new perspective for the study of corporate green innovation. Second, this study enriches the research on the economic consequences of regional happiness. After Chuluun and Graham [8], who studied the relationship between regional happiness and corporate 
investment behavior, our study demonstrates the influence of regional happiness on corporate green innovation and potential channels. The research results provide new empirical evidence for the influence of regional happiness on micro-enterprise behavior. Third, this study extends the determinants of green innovation from environmental regulation to social psychology and provides empirical evidence of the impact of informal institutions on corporate green innovation. Last, we examine the impact of the interaction between formal institutions and regional happiness on corporate green innovation to provide effective guidance and suggestions for promoting environmental sustainability.

The remainder of this paper is organized as follows: Section 2 reviews the literature on happiness and corporate green innovation, Section 3 presents our main hypothesis, Section 4 describes the research design, Section 5 presents the empirical testing results, Section 6 discusses the results, and Section 7 concludes.

\section{Literature Review}

\subsection{Happiness and Regional Happiness}

The core concept of this study is happiness. In fact, happiness constitutes a major research agenda in the field of psychology. Yet, the definition of happiness differs considerably among researchers. Happiness can be divided into subjective well-being (SWB) and psychological well-being (PWB). The former generally refers to people's overall emotional and cognitive evaluation of their quality of life, which is characterized by subjectivity, stability, and integrity [19]. The latter emphasizes the self-presentation of human potential; its six dimensions include autonomy and personal growth [20].

We defined the concept of happiness in this study as people's positive psychological experiences of their own survival and development, which is consistent with Diener's view that subjective happiness is a subjective evaluation of quality of life [19]. The philosophical origin of subjective well-being is hedonistic theory, and the core of SWB is the subjective experience of happiness [21]. Subjective well-being studies try to maximize people's happiness levels [22]. In hedonism psychology, happiness and subjective well-being are equivalent concepts [23]. Therefore, we use happiness to represent our core concept throughout this paper, distinguishing it from psychological well-being.

Luthans et al. [24] pointed out that happiness is a positive psychological state that can be analyzed at the individual, group, and regional levels [25]. In our study, regional happiness is the comprehensive reflection of the positive psychological experiences shared by the citizens of a city. Most studies of regional happiness have been conducted across nations; studies on the factors influencing national happiness have focused on income, government quality, economic growth, social equity, and other aspects [26,27]. In withinnation regional analyses, Glaeser et al. [28] found that people in communities with high inequality were more likely to report lower levels of happiness than those in communities with lower levels of inequality. Lawless and Lucas [29] found a sizable negative correlation between unemployment and happiness at the county level, while Florida [30] showed that human capital — the share of the labor force with at least a bachelor's degree-plays a crucial role in the happiness of metropolitan residents.

\subsection{Economic Consequences of Happiness}

The results of psychological experiments show that emotion is an important factor affecting individual decision-making and greatly influences individual behavior $[31,32]$ For example, positive emotions can affect an individual's ability to innovate and choose, improve memory, and promote altruistic behavior [31]. Ifcher and Zarghamee [32] found that people with positive emotions show a lower level of the time discount factor, promoting long-term benign thinking and positive planning for the future. Happiness is a comprehensive psychological indicator that measures an individual's emotional state; happy people tend to have positive emotions such as optimism and contentment [33]. Emotion is an important factor that affects individual behavior. As an externalized state of emotion, happiness can produce a wide range of behavioral results. Happier individ- 
uals are significantly different from unhappy individuals in their behavior. They smile more in social interactions, create new social contracts quickly, and are more helpful, less absent from work, and less involved in labor disputes [34]. Studies have also shown that happiness can lead to more positive outcomes in personal social interactions, for example, Nelson [35] found that happiness can help individuals obtain long-term social resources. Additionally, happiness can stimulate individual pro-social behaviors [11] and promote altruism [10]. Studies have found that happier people are more likely to make donations [36], and are more willing to cooperate with others and participate in volunteer activities [37]. The positive emotional state brought about by happiness also improves personal productivity [38] and creativity [39], which is beneficial for individuals and provides them with more employment opportunities [40] and a higher income [41]. Existing studies have fully confirmed the income effect of individual happiness [42-44]. Jin [45] added empirical evidence based on macro data to the research in this field and found that the improvement of national happiness and life satisfaction significantly increased the GDP per capita. Happiness also affects social behaviors. For example, happiness increases interest in social activities, resulting in higher quality social interactions [46]. Therefore, happiness can increase individual social capital [13] and reduce residents' intentions to emigrate [47]. These are not directly linked to economic growth, but they guarantee normal economic operations. Other evidence suggests that happiness improves people's health, including improving immunity [48], reducing cardiovascular disease [49], and promoting longevity [50].

With increased research on the economic consequences of happiness, scholars of positive organizational behavior have begun to pay attention to the positive effects of employee happiness on their work performance and innovation capability [51]. These studies regarded employee happiness as a positive emotional experience that could help improve their creativity and stimulate innovative behavior [52]. Happiness can boost voluntary dedication to work, and is an effective way to improve organizational efficiency and achieve higher performance. Happier individuals have more positive emotions, such as optimism, positivity, initiative, and creativity, promoting greater concentration and patience at work, thereby contributing to improved individual productivity and creativity [38]. Shalley et al. [52] found that employee happiness positively correlates with innovation behavior. Enterprises have economic and social attributes, and their economic activities are embedded in the social system on which they depend [6]. Corporate behavior is also affected by regional psychological characteristics, based on the social attributes of enterprises and studies have provided evidence that regional happiness influences enterprise activities. For example, Chuluun and Graham [8] found that regional happiness played a positive role in corporate investment. Heo et al. [9] found that the overall happiness index of a country was positively correlated with corporate capital expenditure, and that companies in countries with a higher level of happiness were more innovative. Research on the relationship between regional happiness and micro-enterprise behavior supports the view that happiness is an important factor in enterprises' activities and economic outcomes. Based on the research of Chuluun and Graham [8] and Heo et al. [9] on regional happiness and corporate investment behavior, this study examines the promotion effect of regional happiness on corporate green innovation, thus providing further evidence for the influence of regional happiness on enterprise activity.

\subsection{Driving Factors of Green Innovation}

In view of the critical role of green innovation in enhancing enterprise value and promoting sustainable economic growth, factors influencing it have become the focus of academic research in recent years. This study reviews these internal and external factors. The macro perspective involves the influence of formal and informal institutions on enterprise innovation, and the enterprise-level factor is mainly about the resources and capabilities required by green innovation. 


\subsubsection{Internal Driving Factors of Green Innovation}

As a special type of innovation [53], the theory used to explain general innovation can also explain the green innovation behavior of enterprises [54,55]. Research based on general innovation theory holds that resources [56] and their effective use [57] are the key to promoting innovation. Similar to general innovation, resources and capabilities are the key factors determining the performance of green innovation. The implementation of green innovation by enterprises is a complex process of resource integration [58], and resource input is an important factor affecting it [59]. Enterprises improve their technological capabilities through continuous investment, which is the main driving force for stimulating green innovation [60]. By establishing cooperative networks with universities, research institutes, suppliers, customers, and even competitors, enterprises can make full use of network resources to supplement the lack of internal human, material, financial, and information resources, thus generating more green innovation [61]. The environmental management system is an important management resource in the process of corporate green innovation It determines the environmental policy of an organization and helps formulate environmental objectives and combine them with performance [62]. Research based on organizational theory focuses on the important role of organizational support factors in green innovation. A formal centralized structure can reduce risks, and realize diversification of resource input, thus improving green innovation performance [53]. Transformational leadership improves green product innovation performance by improving green creativity [63]. Strategic planning is conducive to shaping the common vision of enterprises and enhancing their strategic initiatives, thus improving the performance of green innovation [64]. Additionally, senior management support is key to implementing green innovation and only when senior management is fully aware of the importance of green innovation will enterprises incorporate green innovation into their strategic plans and invest the corresponding human and material resources to realize it $[65,66]$.

\subsubsection{External Driving Factors of Green Innovation}

The traditional view is that environmental improvements brought on by green innovation will inevitably crowd out economic performance, which has become an important factor hindering the implementation of green innovation. Therefore, although many enterprises have realized that green innovation is very important for sustainable development, in practice, few enterprises have taken the initiative to carry out green innovation. As enterprises have low enthusiasm for green innovation, the government needs to stimulate innovation through institutional constraints [67]. Environmental regulation is an effective tool for governments to control environmental pollution. At present, research on the relationship between environmental regulation and green innovation efficiency has not formed a unified view. Porter and Van [68] showed that reasonable environmental regulation plays a positive role in promoting enterprises' technological innovation. Enterprises' production and operation costs can be effectively compensated through the innovation compensation effect, and environmental regulations will force enterprises to carry out internal technological innovation. Zeng [69] and Chen et al. [70] showed that the government's imposition of mandatory tools has a significant positive impact on corporate green innovation. Conversely, an alternative view is that environmental regulations inhibit green innovation, that is, there is no Porter hypothesis. According to this view, environmental regulation essentially impacts the private costs of enterprises, is not conducive to the improvement of enterprises' independent innovation ability and has a restraining effect on economic growth and environmental efficiency. Kneller and Manderson [71] and Yuan [72] found that environmental regulation has an inhibiting effect on enterprises' technological innovation. In addition to environmental regulations, external environment can also affect the green innovation of enterprises through public anger and condemnation, for example, in response to nearby environmental spills, firms may increase both environmental innovation input and output [73]. Zhang and Zhu [74] found that consumer pressure and regulatory pressure have different impacts on green product innovation and green process innova- 
tion through different organizational learning modes. Consumer pressure has a greater positive effect on green product innovation than regulation pressure, whereas regulation pressure is more positively related to green process innovation than consumer pressure. Research shows that enterprises engage in green innovation to pursue the economic value brought by new systems, products, and processes [60] and to meet the market demand for environmentally-friendly products [75]. In addition, recent studies have found that stock market liberalization attracts the attention of securities analysts and increases managers' focus on environmental protection, thereby promoting corporate green innovation [76]. Institutional attention provides comprehensive supervision for enterprises and encourages managers to formulate and implement environmental protection and green development strategies, and to participate in green innovation [77]. Green credit policy has a positive and significant impact on the output of the green innovation of heavily polluting enterprises by alleviating their financial constraints [78].

At present, research on the external environment and corporate green innovation mainly focuses on the formal system dominated by environmental regulation and has not reached a unified conclusion on whether there exists a positive effect of environmental regulation on corporate green innovation, which indicates that the current research may be ignoring important factors that determine corporate green innovation. Pan et al. 1 believes that the existing research on green innovation has its main defects in emphasizing excessively enterprises' formal institutional environments and in neglecting the informal institutional environments. Their results suggest that social trust, as an important informal institution, can reduce financing costs and promote more social responsibility, and is therefore an external driving force for enterprises to upgrade green technology. These studies attempt to explore the cultural factors that influence corporate green innovation and provides further explanation for the varying green innovation levels between different companies in different regions. As the synthesis of a series of positive psychological factors, happiness has been proven to bring many benefits to individuals and enterprises. Green innovation is an inevitable choice for promoting the sustainable development of the economy and society; however, there is no systematic evaluation of how happiness affects corporate green innovation in the existing literature. Therefore, this study takes regional happiness into the analytical framework of the determinants of green innovation and expands the research on the influencing factors of green innovation from the perspective of informal institutions.

\section{Hypotheses Development}

Green innovation mainly refers to innovation activities aimed at promoting the development of green technologies, such as energy conservation, emissions reduction, clean production, and the use of renewable energy. Compared with other innovation activities, green innovation is not only capital intensive, but also associated with high levels of risk, long cycles, and also requires long-term and stable financial support for enterprises to carry out green innovation activities [79]. Solving the problem of financial constraints is a key factor in promoting green innovation [80,81]. Regional happiness plays an important role in improving the efficiency of resource integration and promoting corporate green innovation, because high levels of local happiness play a positive role in enhancing interpersonal communication and social trust. Happiness is a basic psychological resource that influences people's attitudes and behaviors. On the one hand, happiness enhances the sense of trust between people [13], and on the other hand, it promotes the development of regional social networks [82]. Rich social networks enhance enterprises' abilities to seek opportunities and provide those local enterprises with richer resource channels.

Happiness includes a series of related positive emotional states [83] that can promote the expansion of social connections [37]. and increase goodwill between people [84]. Regional happiness is a common positive state of mind, representing a higher level of happiness among individuals in a region. Theoretically, happier individuals tend to have positive emotions, smile more, be sociable in interpersonal communications, and 
have stronger altruistic tendencies and teamwork [41]. Happy individuals help and trust others more, actively return help and kindness to others, and have a higher level of interpersonal trust [13]. Diener and Seligman [85] found that a rich and social life is common among the happiest people, and a willingness to share life with others rather than being alone distinguishes them from the average and unhappy people. With an improvement of happiness, people not only become more positive and cheerful [37], but also more kind [10], while individuals with a higher sense of happiness have a greater ability to empathize with others [35]. Therefore, happier individuals tend to enjoy a higher level of social networking [82]. Regional happiness helps individuals establish positive relationships with others and improves the density and quality of social interactions within a region by promoting social interaction and regional social networks are formed over time through interactions between members [86]. Therefore, at the macro level, a higher level of happiness is likely to promote the development of regional social networks by enriching social networks enjoyed by individuals. In addition, regional happiness promotes greater tolerance and openness within social networks. Cognition and decision-making are strongly influenced by emotions [87]. Positive emotional experiences will enable individuals to perceive others and social events more positively, and greater happiness and satisfaction will lead to a positive bias in their perception of others [84]. The influence of happiness is greater when people are introduced to unfamiliar people, because there are fewer preformed judgments, and decisions are more influenced by emotional states due to the lower degree of cognitive refinement [88]. Happiness increases trust and positive perceptions of cross-group members and promotes the formation of new relationships across different social groups. Therefore, regional happiness contributes to the construction of open social networks. A social network is formed by the interaction between action subjects and the source of corporate information and resources [89], and a social network with an information advantage plays a powerful role in mitigating the problem of information asymmetry in the financing market [90]. Moreover, developed social networks enable a relatively smooth exchange and communication of information and a strong degree of trust between investors and investees, which alleviates information asymmetry and makes enterprises more likely to raise funds for innovative activities [91]. Greater regional happiness means that regional members generally have a more positive emotional state and positive feelings, such as friendliness and tolerance, are constantly strengthened and accumulated until a broad mutual consensus is formed. Meanwhile, happiness reflects the common positive psychology of a region, improves the behavioral consistency of regional members, reduces the cost of social communication, and makes communication across social circles and groups smoother. Therefore, regional happiness reduces the transaction costs for enterprises to obtain the resources needed for green innovation, and enterprises enjoy more channels for information sharing and resource sharing. Thus, enterprises can obtain more financial support to promote green innovation.

Our basic hypothesis is formulated based on these arguments:

Hypothesis 1. Regional happiness has a positive impact on corporate green innovation.

\section{Research Design}

\subsection{Sample and Data}

This study uses the data of A-listed companies on the Shanghai and Shenzhen stock exchanges from 2007 to 2019 as the research sample. The World Intellectual Property Organization (WIPO) provides the definition of green innovation, including technologies related to the disposal of environmental pollutants and climate change mitigation. WIPO provides patent classification numbers for all relevant technologies. To obtain the number of green patents filed by sample companies each year, we obtained the patent classification number information for all A-share listed companies from the Chinese Research Data Services (CNRDS) and matched it with the "Green List of International Patent Classification" issued by the WIPO. The regional happiness data were extracted from the "Top Ten Happiest Cities in China", from 2007 to 2019, published by the Xinhua News Agency. Data on corporate finan- 
cial characteristics were obtained from the China Stock Market and Accounting Research (CSMAR) database. The data were processed by excluding the following: (1) financial industry companies; (2) ST and PT companies, and (3) observations with missing data. In total, 15,610 firm-year observations were obtained from 2419 companies. To avoid the influence of outliers, all continuous variables were winsorized at the upper and lower $1 \%$ levels.

\subsection{Main Variables}

\subsubsection{Dependent Variable}

Referring to Pan et al. [1]. and Chen et al. [70], we used green patent applications to measure the corporate green innovation because patent application data are more stable, reliable, and current than patent grant data. Patent applications provide detailed information about the key characteristics of an underlying invention, which helps to classify innovations according to their technical content [3]. Patents can be divided into invention, utility, and design patents; among these, invention patents have the highest technical thresholds. To apply for green invention patents, enterprises should research and develop, promote, and apply corresponding green technologies to improve the performance of their products. Green invention patents reflect the ability to achieve high-level green innovation [92]. Therefore, in addition to using the total number of green patent applications to measure green innovation, we also used the number of green invention patent applications to measure the quality of green innovation. We took the natural logarithm of one plus the number of green patents filed in an application as the final proxy variable of green innovation, denoted as GINOV1 and GINOV2. In the robustness test, we re-measured the green innovation based on the number of green patents granted.

\subsubsection{Independent Variable}

Referring to Xiu and Zhou [93], we constructed city-level happiness variables based on the survey results of the "Happiest Cities in China". The "Happiest Cities in China" survey is sponsored by the Xinhua News Agency and more than one billion people have participated in the survey. Since the questionnaire survey is affected by the emotional state of its respondents when filling in the questionnaire, and since their responses may change based on the wording of the survey's questions, the ranking of happiness in a single year may not be a reliable measure of regional happiness. Therefore, this study constructs happiness variables based on Hangzhou, Chengdu, Changsha, and Nanjing, as they are listed most frequently among the "Top Ten Happiest Cities in China" from 2007 to 2019 [93]. The contagion effect of happiness is strengthened by the proximity or the geographical distance between regions [94], i.e., regions that are close to each other have similar development patterns and lifestyles, and there is more frequent social interaction between neighboring regions, which makes it easier for adjacent regions to develop similar levels of happiness. Because geographical distance is strictly exogenous, it can overcome the endogeneity problem to some extent. Therefore, this study constructs regional happiness variables according to geographical distance. We used "Google Maps" to collect the geographic coordinates of the cities in which the enterprises are registered and for Hangzhou, Chengdu, Changsha, and Nanjing. Next, we calculated the geographical distance between the cities where the enterprises are registered and Hangzhou, Chengdu, Changsha, and Nanjing. The closer the distance between the enterprise's registered city and the four cities, the greater the residents' levels of happiness in the enterprises' locations. We measured regional happiness as the negative natural logarithm of one plus the minimum of the four distance values [93], which was expressed as HAPP_DIS. The larger the value, the higher the level of regional happiness. We defined the dummy variable as HAPP. When the company was located in Hangzhou, Chengdu, Changsha, or Nanjing, the HAPP equaled 1, and in other cases, the HAPP equaled 0 . In the robustness test, we re-measured regional happiness by examining the emotional state conveyed by social media. 


\subsubsection{Control Variables}

We introduced a series of control variables to control for other economic characteristics affecting corporate green innovation [13,95] including enterprise size (SIZE), financial leverage (LEV), company performance (ROA), growth rate (GROWTH), largest ownership (SHR1), board independence (INDEP), managerial ownership (MSHARE), CEO duality (Dual), ownership (SOE), cash flow (CASH), and intensity of physical assets (PPE). As the regional innovation policy environment may have influenced the corporate green innovation activities, we also controlled for the intensity of provincial R\&D expenditure (RDI). The level of regional economic development has an important impact on enterprise green innovation; therefore, we further controlled the per capita GDP of the city. In addition, the industry dummy variable, IND, and annual dummy variable, YEAR, were added to control for the influence of industry or macroeconomic factors in the regression analysis results. Table 1 presents the detailed definitions and construction of the variables.

Table 1. Variable definitions.

\begin{tabular}{|c|c|c|c|}
\hline Variable & Explanation & Definition & Data Source \\
\hline GINOV1 & Green innovation & $\begin{array}{l}\text { Natural logarithm of } 1 \text { plus the } \\
\text { aggregate number of green patents filed } \\
\text { in application. }\end{array}$ & CNRDS \\
\hline GINOV2 & Green innovation & $\begin{array}{l}\text { Natural logarithm of } 1 \text { plus the } \\
\text { aggregate number of green invention } \\
\text { patents filed in application. }\end{array}$ & CNRDS \\
\hline & & $\begin{array}{l}\text { Add } 1 \text { to the minimum geographical } \\
\text { distance between the registered city and } \\
\text { Hangzhou, Chengdu, Changsha, and }\end{array}$ & \\
\hline HAPP_DIS & Regional happiness & $\begin{array}{c}\text { Nanjing, then take the natural number, } \\
\text { and then take the negative number. The } \\
\text { higher the value, the greater the level } \\
\text { of happiness. }\end{array}$ & Xinhua News Agency \\
\hline HAPP & Regional happiness & $\begin{array}{c}\text { Equal to } 1 \text { when the registered city is } \\
\text { Hangzhou, Chengdu, Changsha, or } \\
\text { Nanjing, otherwise equal to } 0 .\end{array}$ & Xinhua News Agency \\
\hline SIZE & Firm size & $\begin{array}{c}\text { The natural logarithm of total assets at } \\
\text { the fiscal year end. }\end{array}$ & CSMAR \\
\hline LEV & Financial leverage & The ratio of total liabilities to total assets. & CSMAR \\
\hline ROA & Return on assets & The ratio of net income to total assets. & CSMAR \\
\hline GROWTH & Growth rate & $\begin{array}{l}\text { The ratio of operating income change to } \\
\text { operating income in the previous period } \\
\text { at every year end. }\end{array}$ & CSMAR \\
\hline SHR1 & Largest ownership & $\begin{array}{c}\text { The percentage ownership of the } \\
\text { largest shareholder. }\end{array}$ & CSMAR \\
\hline INDEP & Board independence & $\begin{array}{l}\text { The percentage of independent } \\
\text { members on a board. }\end{array}$ & CSMAR \\
\hline MSHARE & Managerial ownership & $\begin{array}{l}\text { Percentage of shares held by directors, } \\
\text { supervisors, and senior managers. }\end{array}$ & CSMAR \\
\hline DUAL & CEO duality & $\begin{array}{l}\text { A dummy variable which equals one if } \\
\text { the firm's board chair is also its CEO } \\
\text { and zero otherwise. }\end{array}$ & CSMAR \\
\hline SOE & Ownership & $\begin{array}{c}\text { A dummy variable that equals one if a } \\
\text { firm is a state-owned enterprise and } \\
\text { zero otherwise. }\end{array}$ & CSMAR \\
\hline CASH & Cash flow & $\begin{array}{c}\text { The ratio of net cash flow from } \\
\text { operations to total assets. }\end{array}$ & CSMAR \\
\hline PPE & Intensity of physical assets & $\begin{array}{l}\text { The ratio of net property, plant, and } \\
\text { equipment to total assets. }\end{array}$ & CSMAR \\
\hline RDI & Regional R\&D intensity & $\begin{array}{c}\text { The ratio of annual R\&D expenditure } \\
\text { within the province where the enterprise } \\
\text { is located to annual GDP of } \\
\text { the province. }\end{array}$ & $\begin{array}{c}\text { China Statistical Yearbook of Science } \\
\text { and Technology.; National Bureau of } \\
\text { Statistics of China. }\end{array}$ \\
\hline GDP & Regional economic development & $\begin{array}{c}\text { The natural logarithm of GDP per capita } \\
\text { in the city where the enterprise } \\
\text { is located. }\end{array}$ & National Bureau of Statistics of China. \\
\hline
\end{tabular}




\subsection{Regression Models}

A baseline model was constructed based on Hypothesis 1 to test the influence of regional happiness on corporate green innovation:

$$
\begin{gathered}
\text { GINOV }_{i t}=\beta_{0}+\beta_{1} H A P P \_D I S / H A P P_{i t}+\beta_{2} \text { SIZE }_{i t}+\beta_{3} L E V_{i t}+\beta_{4} R O A_{i t}+ \\
\beta_{5} \text { GROWTH }_{i t}+\beta_{6} S H R 1_{i t}+\beta_{7} I N D E P_{i t}+\beta_{8} M S H A R E_{i t}+\beta_{9} D U A L_{i t}+\beta_{10} S O E_{i t}+ \\
\beta_{11} \text { CASH }_{i t}+\beta_{12} P P E_{i t}+\beta_{13} R D I_{i t}+\beta_{14} G D P_{i t}+\sum Y E A R+\sum I N D+\varepsilon_{i t}
\end{gathered}
$$

In the above model, $\beta_{0}$ is the intercept parameter, and $\varepsilon$ is the error term. GINOV $\mathrm{Gi}_{\text {it }}$ represents green innovation, including two variables: GINOVA $1_{i t}$ and GINOV $2_{i t}$. HAPP_DIS/ $\mathrm{HAPP}_{\text {it }}$ represents the regional happiness level. Hypothesis 1 is supported if the estimated coefficient of HAPP_DIS/HAPP it in model (1) is significantly positive.

\section{Empirical Testing Results}

\subsection{Correlation Analysis}

Table 2 summarizes the Pearson and Spearman correlation coefficient matrices of the variables. The correlation coefficient between the HAPP_DIS and GINOV1 is positive, but not significant, indicating that the relationship between regional happiness and corporate green innovation needs to be further analyzed. At the same time, most control variables were significantly correlated with enterprise green innovation at the $1 \%$ level, indicating that it was necessary to conduct multiple regression analyses to exclude the influence of these variables. The correlations between other variables were also reasonable. For example, GROWTH was significantly positively correlated with ROA, indicating that a company with better growth had better profitability. LEV was significantly negatively correlated with ROA, indicating that the companies with high financial leverage had worse profitability. Although the correlation coefficients between the independent variables were significant, the maximum value of multicollinearity, tested by the variance inflation factor, was 1.78 , which was lower than the empirical value of 5 . Therefore, there was no serious multicollinearity problem between the independent variables in the model.

\subsection{Descriptive Statistics}

Table 3 summarizes the descriptive statistical results of the variables. The mean value of total green patent applications (GINOV1) was 1.106 and for green invention patent applications (GINOV2) it was 0.766, indicating that, on the whole, high-quality green innovation in the sample of companies accounts for a large proportion of the total green innovation. The standard deviations of total green patent applications (GINOV1) and green invention patent applications (GINOV2) were both greater than the mean value, indicating that there were great differences in green innovation levels in the sample of companies. The minimum value of financial leverage (Lev) was 0.056 , while the maximum value was 0.894 , indicating great differences in financial leverage in the sample. In addition, the minimum value of Growth was -0.518 , while the maximum value was 2.475 , indicating that the growth of the sample companies also had great differences. The mean value of SOE was 0.395 , indicating that most of the sample's companies were not state-owned enterprises.

\subsection{Baseline Regression}

Table 4 reports the regression results for model (1). As can be seen from columns (1) and (2) of Table 4, the regression coefficients of HAPP_DIS on the total green patent applications (GINOV1) and green invention patent applications (GINOV2) were 0.029 and 0.026 , respectively; both are statistically significant at the $1 \%$ level, indicating that corporate green innovation increases with an improvement of regional happiness. The estimated coefficients of happiness variables in columns (3) and (4) of Table 4 are significantly positive, indicating that regional happiness not only improved the quantity of green innovation, but also improved the quality of green innovation. The above results therefore support Hypothesis 1. 
Table 2. Correlation matrix

\begin{tabular}{|c|c|c|c|c|c|c|c|c|c|c|c|c|c|c|c|c|c|}
\hline Variable & GINOV1 & GINOV2 & HAPP_DIS & HAPP & SIZE & LEV & ROA & GROWTH & SHR1 & INDEP & DUAL & MSHARE & SOE & CASH & PPE & RDI & GDP \\
\hline GINOV1 & 1 & $0.886^{* * * *}$ & 0.004 & $0.027^{* * *}$ & $0.312^{* * * *}$ & $0.179^{* * * *}$ & $0.020^{* *}$ & $0.091^{* * *}$ & $0.031^{* * *}$ & 0.002 & $-0.053^{* * *}$ & $-0.035^{* * *}$ & $0.116^{* * * *}$ & $-0.023^{* * *}$ & $-0.032^{* * *}$ & $0.075^{* * * *}$ & $0.069^{* * * *}$ \\
\hline GINOV2 & $0.925^{* * *}$ & 1 & 0.007 & $0.029 * * *$ & $0.302^{* * * *}$ & $0.144^{* * *}$ & $0.035^{* * * *}$ & $0.079^{* * * *}$ & $0.017^{\text {** }}$ & $0.014^{*}$ & -0.039 **** & $-0.033^{* * * *}$ & $0.115^{* * *}$ & -0.006 & $-0.060^{* * * *}$ & $0.099^{* * *}$ & $0.090^{* * * *}$ \\
\hline HAPP_DIS & 0.007 & 0.010 & 1 & $0.520^{* * * *}$ & $-0.089^{* * * *}$ & $-0.054^{* * * *}$ & $0.050^{* * * *}$ & -0.005 & -0.012 & $-0.029^{* * *}$ & 0.003 & $0.073^{* * * *}$ & $-0.080^{* * * *}$ & $0.032^{* * * *}$ & 0.006 & $0.041^{* * *}$ & $-0.025^{* * * *}$ \\
\hline HAPP & $0.020^{* *}$ & $0.022^{* * * * *}$ & $0.913^{* * * *}$ & 1 & $-0.038^{* * * *}$ & -0.008 & $0.023^{* * * *}$ & 0.001 & $0.021^{* * * * *}$ & -0.006 & -0.012 & $0.060^{* * *}$ & $-0.042^{* * *}$ & -0.007 & $-0.080^{* * * *}$ & -0.050 & $0.097^{* * * *}$ \\
\hline SIZE & $0.397^{* * *}$ & $0.393^{* * *}$ & $-0.075^{* * *}$ & $-0.044^{* * *}$ & 1 & $0.533^{* * *}$ & $-0.060^{* * * *}$ & $0.035^{* * * *}$ & $0.191^{* * *}$ & $-0.015^{*}$ & $-0.198^{* * *}$ & $-0.334^{* * *}$ & $0.370^{* * * *}$ & $0.086^{* * * *}$ & $0.069^{\text {**** }}$ & -0.008 & -0.010 \\
\hline LEV & $0.195^{* * *}$ & $0.164^{* * * *}$ & $-0.034^{* * * *}$ & -0.007 & $0.523^{* * *}$ & 1 & $-0.416^{* *+4}$ & -0.006 & $0.085^{* * * *}$ & -0.010 & $-0.154 * * *$ & $-0.340^{* * * *}$ & $0.323^{* * * *}$ & $-0.133^{* * *}$ & $0.062^{* * *}$ & $-0.105^{* * *}$ & $-0.065^{* * * *}$ \\
\hline ROA & $0.021^{* * * *}$ & $0.031^{* * * *}$ & $0.031^{* * * *}$ & $0.017^{* *}$ & 0.002 & $-0.368^{* * * *}$ & 1 & $0.314^{* * * *}$ & $0.082^{* * * *}$ & $-0.032^{* * * *}$ & $0.069^{* * * *}$ & $0.219^{* *+*}$ & $-0.171^{* * * *}$ & 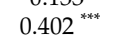 & $-0.119^{* * * *}$ & $0.099^{* * * *}$ & $0.081^{* * * *}$ \\
\hline GROWTH & $0.043^{* * *}$ & $0.035^{* * *}$ & -0.012 & -0.008 & $0.038^{* * * *}$ & $0.022^{* * *}$ & $0.219^{* * * *}$ & 1 & $-0.025^{* * *}$ & 0.007 & $0.058^{* * * *}$ & $0.161^{* * *}$ & $-0.125 * * *$ & $0.036^{* * * *}$ & $-0.120^{* * *}$ & $0.037^{* * * *}$ & $0.057^{* * * *}$ \\
\hline SHR1 & $0.055^{* * *}$ & $0.044^{* * * *}$ & 0.005 & $0.014^{*}$ & $0.239^{* * *}$ & $0.087^{* * *}$ & $0.099^{* * * *}$ & -0.004 & 1 & $0.032^{* * * *}$ & $-0.063^{* * *}$ & $-0.261^{* * * *}$ & $0.255^{* * * *}$ & $0.093^{* * * *}$ & $0.083^{* * * *}$ & 0.003 & $-0.024^{* * * *}$ \\
\hline INDEP & $0.025^{* * * *}$ & $0.034^{* * * *}$ & $-0.020^{* *}$ & $\begin{array}{l}0.007 \\
-0.007\end{array}$ & 0.019 ** & -0.001 & $-0.028^{* * *+}$ & -0.004 & $0.039^{* * * *}$ & 1 & $0.105^{* * * *}$ & $0.047^{*+2 \times t}$ & $-0.072^{* * * *}$ & $-0.024^{* * * *}$ & $-0.045^{* * * *}$ & $0.026^{* * * *}$ & $0.058^{* * * *}$ \\
\hline DUAL & $-0.057^{* * *}$ & $-0.043^{* * *}$ & -0.003 & -0.012 & $-0.189^{* * * *}$ & $-0.153^{* * *}$ & $0.046^{*}$ & $0.038^{* * * *}$ & $-0.071^{* * *}$ & $0.108^{* * *}$ & 1 & $0.271 * * *$ & $-0.304 * * *$ & $\begin{array}{l}-0.022 * * * * \\
-0.022^{*}\end{array}$ & $-0.090^{* * * *}$ & $0.088^{* * * *}$ & $0.115^{* * * *}$ \\
\hline SOE & $0.126^{\text {**** }}$ & $0.128^{* * * *}$ & $-0.070 * * *$ & $-0.042^{* * * *}$ & $0.377^{* * * *}$ & $0.325^{* * * * *}$ & $-0.109^{* * *+}$ & $-0.095^{* * * *}$ & $0.256^{* * * *}$ & $-0.068^{* * * *}$ & $-0.304^{* * * *}$ & $-0.513^{* * *}$ & 1 & 0.012 & $0.172^{* * * * *}$ & $-0.128^{* * * *}$ & $-0.165^{* * * *}$ \\
\hline CASH & -0.009 & $\begin{array}{l}0.120 \\
0.007\end{array}$ & 0.010 & -0.006 & $0.084^{* * * *}$ & $-0.148^{* * * *}$ & 0.390 & -0.002 & $0.094^{* * * *}$ & $-0.016^{* * *}$ & $-0.023^{* * * *}$ & $-0.023^{* * * *}$ & 0.010 & 1 & $0.264^{* * * *}$ & 0.003 & -0.006 \\
\hline PPE & $-0.028^{* * * *}$ & $-0.049^{* * *}$ & $-0.070^{* * * *}$ & $-0.077^{* * * *}$ & $0.142^{* * *}$ & $0.116^{* * * *}$ & $-0.114^{* *+*}$ & $-0.099^{* * * *}$ & $0.104^{* * * *}$ & $-0.043^{* * * *}$ & $-0.108^{* * * *}$ & $-0.194 * * *$ & $0.223^{* * * *}$ & $0.249^{* * *}$ & 1 & $-0.226^{* * * *}$ & $-0.248^{* * *+*}$ \\
\hline RDI & $0.116^{* * * *}$ & $0.141^{* * * * *}$ & $-0.100^{* * * *}$ & $-0.096^{* * * *}$ & $0.061^{* * *}$ & $-0.078^{* * * *}$ & $0.053^{* * *+1}$ & $0.018^{* * *}$ & $0.034^{* * * *}$ & $0.031^{* * * *}$ & $0.055^{* * * *}$ & $0.109^{* * * *}$ & $-0.047^{* * * *}$ & $-0.014^{*}$ & $-0.196^{* * * *}$ & 1 & $0.538^{* * * *}$ \\
\hline GDP & $0.074^{* * * *}$ & $0.087^{* * * *}$ & 0.001 & $0.049^{* * * 4 *}$ & 0.001 & $-0.051^{* * * *}$ & $0.031^{* * * *}$ & $0.023^{* * * *}$ & $\begin{array}{l}0.034 \\
-0.021^{* * *}\end{array}$ & $0.055^{* * * *}$ & $0.123^{* * * *}$ & $0.161^{* * * *}$ & $-0.160^{* * *}$ & $\begin{array}{l}-0.023^{* * * *} \\
-0.07\end{array}$ & $-0.223^{* * * *}$ & $0.316^{* * * *}$ & 1 \\
\hline
\end{tabular}

Notes: This table presents the correlation matrix of the variables used in our analysis. The variable definitions are presented in Table $1 .{ }^{*},{ }^{* *}$, and ${ }^{* * *}$ indicate two-tailed significance at the $10 \%, 5 \%$, and $1 \%$ levels, respectively. Pearson correlation coefficients are shown above the diagonal, and the Spearman correlation coefficients are below the diagonal. 
Table 3. Descriptive statistics.

\begin{tabular}{ccccccc}
\hline Variable & Obs. & Mean & $\begin{array}{c}\text { Standard } \\
\text { Deviation }\end{array}$ & Minimum & Median & Maximum \\
\hline GINOV1 & 15,610 & 1.106 & 1.216 & 0.000 & 0.693 & 4.963 \\
GINOV2 & 15,610 & 0.766 & 1.039 & 0.000 & 0.000 & 4.431 \\
HAPP_DIS & 15,610 & -5.420 & 1.975 & -7.635 & -6.299 & 0.000 \\
HAPP & 15,610 & 0.100 & 0.299 & 0.000 & 0.000 & 1.000 \\
SIZE & 15,610 & 22.291 & 1.322 & 19.951 & 22.091 & 26.369 \\
LEV & 15,610 & 0.436 & 0.204 & 0.056 & 0.432 & 0.894 \\
ROA & 15,610 & 0.038 & 0.056 & -0.217 & 0.036 & 0.187 \\
GROWTH & 15,610 & 0.187 & 0.402 & -0.518 & 0.119 & 2.475 \\
SHR1 & 15,610 & 0.345 & 0.151 & 0.085 & 0.321 & 0.751 \\
INDEP & 15,610 & 0.374 & 0.053 & 0.333 & 0.333 & 0.571 \\
MSHARE & 15,610 & 0.130 & 0.195 & 0.000 & 0.004 & 0.688 \\
SOE & 15,610 & 0.395 & 0.489 & 0.000 & 0.000 & 1.000 \\
DUAL & 15,610 & 0.259 & 0.438 & 0.000 & 0.000 & 1.000 \\
CASH & 15,610 & 0.044 & 0.067 & -0.153 & 0.043 & 0.231 \\
PPE & 15,610 & 0.215 & 0.159 & 0.003 & 0.180 & 0.698 \\
RDI & 15,610 & 0.025 & 0.014 & 0.005 & 0.022 & 0.062 \\
GDP & 15,610 & 11.501 & 0.731 & 9.810 & 11.523 & 13.135 \\
\hline
\end{tabular}

Table 4. Regional happiness and green innovation.

\begin{tabular}{|c|c|c|c|c|}
\hline Variable & $\begin{array}{c}\text { (1) } \\
\text { GINOV1 }\end{array}$ & $\begin{array}{c}\text { (2) } \\
\text { GINOV1 }\end{array}$ & $\begin{array}{c}\text { (3) } \\
\text { GINOV2 }\end{array}$ & $\begin{array}{c}\text { (4) } \\
\text { GINOV2 }\end{array}$ \\
\hline HAPP_DIS & $\begin{array}{c}0.029^{* * *} \\
(7.04)\end{array}$ & & $\begin{array}{c}0.026^{* * *} \\
(7.21)\end{array}$ & \\
\hline HAPP & & $\begin{array}{c}0.177^{* * *} \\
(6.42)\end{array}$ & & $\begin{array}{c}0.151^{* * *} \\
(6.26)\end{array}$ \\
\hline SIZE & $\begin{array}{c}0.426^{* * *} \\
(50.73)\end{array}$ & $\begin{array}{l}0.424^{* * *} \\
(50.61)\end{array}$ & $\begin{array}{c}0.373^{* * *} \\
(50.71)\end{array}$ & $\begin{array}{c}0.372^{* * *} \\
(50.57)\end{array}$ \\
\hline LEV & $\begin{array}{l}0.061 \\
(1.10)\end{array}$ & $\begin{array}{l}0.060 \\
(1.08)\end{array}$ & $\begin{array}{c}-0.086 \\
(-1.76)\end{array}$ & $\begin{array}{c}-0.087^{*} \\
(-1.78)\end{array}$ \\
\hline ROA & $\begin{array}{c}0.618^{* * *} \\
(3.35)\end{array}$ & $\begin{array}{c}0.625^{* * *} \\
(3.39)\end{array}$ & $\begin{array}{c}0.379^{* *} \\
(2.34)\end{array}$ & $\begin{array}{c}0.386 \\
(2.39)\end{array}$ \\
\hline GROWTH & $\begin{array}{l}-0.012 \\
(-0.55)\end{array}$ & $\begin{array}{l}-0.012 \\
(-0.58)\end{array}$ & $\begin{array}{l}-0.015 \\
(-0.80)\end{array}$ & $\begin{array}{l}-0.015 \\
(-0.83)\end{array}$ \\
\hline SHR1 & $\begin{array}{c}-0.222^{* * *} \\
(-3.87)\end{array}$ & $\begin{array}{c}-0.220^{* * *} \\
(-3.83)\end{array}$ & $\begin{array}{c}-0.262^{* * *} \\
(-5.19)\end{array}$ & $\begin{array}{c}-0.259^{* * *} \\
(-5.15)\end{array}$ \\
\hline INDEP & $\begin{array}{l}0.187 \\
(1.22)\end{array}$ & $\begin{array}{l}0.174 \\
(1.14)\end{array}$ & $\begin{array}{c}0.328^{* *} \\
(2.44)\end{array}$ & $\begin{array}{c}0.316^{* *} \\
(2.35)\end{array}$ \\
\hline MSAHRE & $\begin{array}{l}0.020 \\
(0.39)\end{array}$ & $\begin{array}{l}0.016 \\
(0.31)\end{array}$ & $\begin{array}{c}-0.074^{*} \\
(-1.65)\end{array}$ & $\begin{array}{c}-0.078 \\
(-1.73)\end{array}$ \\
\hline SOE & $\begin{array}{c}0.060^{* * *} \\
(2.83)\end{array}$ & $\begin{array}{c}0.056^{* * *} \\
(2.63)\end{array}$ & $\begin{array}{c}0.090^{* * *} \\
(4.81)\end{array}$ & $\begin{array}{c}0.086^{* * *} \\
(4.60)\end{array}$ \\
\hline DUAL & $\begin{array}{l}-0.010 \\
(-0.50)\end{array}$ & $\begin{array}{l}-0.010 \\
(-0.49)\end{array}$ & $\begin{array}{l}0.024 \\
(1.40)\end{array}$ & $\begin{array}{l}0.024 \\
(1.41)\end{array}$ \\
\hline CASH & $\begin{array}{c}-0.292^{* *} \\
(-2.08)\end{array}$ & $\begin{array}{c}-0.280 \\
(-1.99)\end{array}$ & $\begin{array}{l}-0.068 \\
(-0.55)\end{array}$ & $\begin{array}{c}-0.057 \\
(-0.47)\end{array}$ \\
\hline PPE & $\begin{array}{c}-0.550^{* * *} \\
(-8.42)\end{array}$ & $\begin{array}{c}-0.551^{* * *} \\
(-8.44)\end{array}$ & $\begin{array}{c}-0.603^{* * *} \\
(-10.53)\end{array}$ & $\begin{array}{l}-0.605^{* * *} \\
(-10.57)\end{array}$ \\
\hline RDI & $\begin{array}{c}5.897^{* * *} \\
(9.33)\end{array}$ & $\begin{array}{c}5.930^{* * *} \\
(9.36)\end{array}$ & $\begin{array}{c}6.117^{* * *} \\
(11.04)\end{array}$ & $\begin{array}{c}6.123^{* * *} \\
(11.02)\end{array}$ \\
\hline GDP & $\begin{array}{c}0.081^{* * *} \\
(6.46)\end{array}$ & $\begin{array}{c}0.076^{* * *} \\
(6.10)\end{array}$ & $\begin{array}{c}0.066^{* * *} \\
(6.04)\end{array}$ & $\begin{array}{c}0.062^{* * *} \\
(5.69)\end{array}$ \\
\hline Constant & $\begin{array}{l}-9.373^{* * *} \\
(-39.63)\end{array}$ & $\begin{array}{l}-9.464^{* * *} \\
(-40.05)\end{array}$ & $\begin{array}{l}-8.368^{* * *} \\
(-40.34)\end{array}$ & $\begin{array}{l}-8.450 \\
(-40.77)\end{array}$ \\
\hline YEAR & Yes & Yes & Yes & Yes \\
\hline IND & Yes & Yes & Yes & Yes \\
\hline Obs. & 15610 & 15610 & 15610 & 15610 \\
\hline Adj. $R^{2}$ & 0.320 & 0.319 & 0.283 & 0.283 \\
\hline
\end{tabular}

Notes: This table provides the results of estimating the regression Model (1). The definitions of the variables are provided in Table 1 . The values between parentheses are t-statistics. ${ }^{*},{ }^{* *}$, and ${ }^{* * *}$ indicate two-tailed significance at the $10 \%, 5 \%$, and $1 \%$ levels, respectively. 


\subsection{Robustness Checks}

\subsubsection{Endogeneity Concerns}

The endogenous problem of regional happiness may lead to deviations in the above estimates. Regional happiness and the local enterprises' green innovation may have been jointly affected by unobtrusive factors. Although the regional R\&D intensity and economic development level were controlled in the regression, there is still a possibility that the variables related to corporate green innovation were positively correlated with regional happiness. There is also a reverse causal mechanism in the above estimation, that is, green innovation made the enterprises more competitive, thus improving the regional economic development and happiness levels. An effective way to solve the problem of missing variables and reverse causality is to look for instrumental variables. Architecture reflects both people and society, and also acts on people and society, thus restricting people's ideas and behaviors. Compared to the asset property of a house, the residential property of the house, namely, the number of rooms and the per capita area of the house, has a significant positive impact on residents' happiness [96]. Therefore, we took the natural logarithm of the per capita housing area of a city as an instrumental variable for regional happiness, which was expressed by SPACE. At present, there is no theoretical or empirical evidence linking per capita housing area with green innovation, and the expected instrumental variables met the exclusion constraints. The first-stage regression results are shown in Column (1) of Table 5. The estimated coefficient of SPACE was significantly positive at the $1 \%$ level. The Kleibergen-Paap F statistic value was higher than the critical value of Stock and Yogo [97], indicating that the instrumental variables were correlated. The regression results of the two stages are shown in columns (2) and (3) of Table 5 and are consistent with the main empirical results (Table 4). The coefficient of happiness variables was still positive and significant at the $1 \%$ level. This suggests that the previous results hold after controlling for the underlying endogeneity problems.

\subsubsection{Alternative Measurements for Green Innovation}

Enterprises' patent applications, especially invention patent applications, can be granted patent authorization only after a strict review process. The number of patents granted may represent the actual value of green innovation. We employed two alternative measures of corporate green innovation: GINVG1 and GINVG2. GINVG1 is the natural logarithm of the total number of green patents granted, plus 1. GINVG2 is the natural logarithm of the total number of green invention patents granted plus 1 . The estimation results based on GINVG1 and GINVG2 are presented in Table 6. The results show that a change in the measure of dependent variables did not alter our main results.

\subsubsection{Measure of Regional Happiness based on an Analysis of Social Media Sentiment}

Due to the popularity of social media, some scholars have analyzed geographical differences in happiness by judging the emotional states conveyed by tweets and microblog posts $[98,99]$. Following Zheng et al. [99], we reconstructed regional happiness variables through a corpus analysis of Sina Weibo and used the Tencent Natural Language Processing (NLP) platform to measure the emotion of 2,0688,900 geo-tagged microblogs published from 2010 to 2019. We used the Tencent NLP platform to measure emotions on Sina Weibo. By calculating the annual average and median emotional values of microblogs located in each city, we constructed the city-level happiness index, which was represented as Happs1 and Happs2. This new regional happiness index was used to re-implement the regression between happiness and corporate green innovation. The regression results shown in Table 7 indicate that the promoting effect of happiness on corporate green innovation had not changed.

\subsection{Discussions of the Mechanism}

Our analysis shows that regional happiness helps enterprises expand resource channels, overcome financing constraints, and eventually establish a positive relationship with 
corporate green innovation. Therefore, we examined potential channels from the perspective of financing constraints.

Referring to Kaplan and Zingales [100] and Whited and Wu [101], we used the KZ index (KZ) and WW index (WW) as proxy variables of financing constraints. The larger the values in the $\mathrm{KZ}$ index and WW index, the higher the degree of financing constraints a company faced. Regional happiness was expected to reduce the enterprises' financing constraints. Columns (1) and (2) in Table 8 report the regression results of Happ_DIS on the KZ index and WW index, respectively. The estimated coefficient of Happ_DIS was significantly negative at the $10 \%$ and $1 \%$ levels, indicating that regional happiness can alleviate the financing constraints faced by enterprises, thus ensuring enterprises implement green innovation.

Table 5. Two-stage least-squares regressions.

\begin{tabular}{|c|c|c|c|}
\hline Variable & $\begin{array}{c}\text { (1) } \\
\text { HAPP_DIS }\end{array}$ & $\begin{array}{c}\text { (2) } \\
\text { GINOV1 }\end{array}$ & $\begin{array}{c}\text { (3) } \\
\text { GINOV2 }\end{array}$ \\
\hline SPACE & $\begin{array}{c}0.192^{* * *} \\
(94.85)\end{array}$ & & \\
\hline Instrument_HAPP_DIS & & $\begin{array}{c}0.049^{* * *} \\
(7.08)\end{array}$ & $\begin{array}{c}0.046^{* * *} \\
(7.57)\end{array}$ \\
\hline SIZE & $\begin{array}{c}-0.046^{* * *} \\
(-3.61)\end{array}$ & $\begin{array}{c}0.426^{* * *} \\
(50.58)\end{array}$ & $\begin{array}{c}0.374^{* * *} \\
(50.64)\end{array}$ \\
\hline LEV & $\begin{array}{c}0.313^{* * * *} \\
(3.67)\end{array}$ & $\begin{array}{l}0.069 \\
(1.24)\end{array}$ & $\begin{array}{l}-0.083^{*} \\
(-1.70)\end{array}$ \\
\hline ROA & $\begin{array}{l}0.034 \\
(0.12)\end{array}$ & $\begin{array}{c}0.600^{* * * *} \\
(3.25)\end{array}$ & $\begin{array}{c}0.362^{* *} \\
(2.23)\end{array}$ \\
\hline GROWTH & $\begin{array}{c}-0.0999^{* * *} \\
(-3.07)\end{array}$ & $\begin{array}{l}-0.007 \\
(-0.35)\end{array}$ & $\begin{array}{l}-0.011 \\
(-0.62)\end{array}$ \\
\hline SHR1 & $\begin{array}{c}0.498^{* * * *} \\
(5.64)\end{array}$ & $\begin{array}{c}-0.233^{* * *} \\
(-4.04)\end{array}$ & $\begin{array}{c}-0.273^{* * *} \\
(-5.37)\end{array}$ \\
\hline INDEP & $\begin{array}{l}-0.216 \\
(-0.92)\end{array}$ & $\begin{array}{l}0.222 \\
(1.45)\end{array}$ & $\begin{array}{c}0.357^{* * *} \\
(2.65)\end{array}$ \\
\hline MSAHRE & $\begin{array}{l}0.076 \\
(0.97)\end{array}$ & $\begin{array}{l}0.012 \\
(0.23)\end{array}$ & $\begin{array}{c}-0.080 \\
(-1.77)\end{array}$ \\
\hline SOE & $\begin{array}{l}-0.026 \\
(-0.78)\end{array}$ & $\begin{array}{c}0.069^{* * *} \\
(3.20)\end{array}$ & $\begin{array}{c}0.097^{* * *} \\
(5.16)\end{array}$ \\
\hline DUAL & $\begin{array}{l}-0.040 \\
(-1.31)\end{array}$ & $\begin{array}{l}-0.003 \\
(-0.17)\end{array}$ & $\begin{array}{c}0.029^{*} \\
(1.68)\end{array}$ \\
\hline CASH & $\begin{array}{l}0.378^{*} \\
(1.75)\end{array}$ & $\begin{array}{c}-0.284^{* *} \\
(-2.01)\end{array}$ & $\begin{array}{l}-0.066 \\
(-0.53)\end{array}$ \\
\hline PPE & $\begin{array}{c}-0.839 \text { *** } \\
(-8.39)\end{array}$ & $\begin{array}{c}-0.544^{* * * *} \\
(-8.30)\end{array}$ & $\begin{array}{c}-0.596^{* * *} \\
(-10.35)\end{array}$ \\
\hline RDI & $\begin{array}{c}-15.658^{* * *} \\
(-16.26)\end{array}$ & $\begin{array}{c}6.262^{* * *} \\
(9.77)\end{array}$ & $\begin{array}{c}6.477^{* * *} \\
(11.52)\end{array}$ \\
\hline GDP & $\begin{array}{l}0.572^{* * * *} \\
(28.40)\end{array}$ & $\begin{array}{c}0.081^{* * *} \\
(6.46)\end{array}$ & $\begin{array}{c}0.067^{* * *} \\
(6.08)\end{array}$ \\
\hline Constant & $\begin{array}{c}-16.9511^{* * *} \\
(-43.73)\end{array}$ & $\begin{array}{c}-9.931^{* * *} \\
(-42.45)\end{array}$ & $\begin{array}{c}-8.608^{* * *} \\
(-41.92)\end{array}$ \\
\hline YEAR & Yes & Yes & Yes \\
\hline IND & Yes & Yes & Yes \\
\hline Obs. & 15524 & 15524 & 15524 \\
\hline$R^{2}$ & 0.3987 & 0.3195 & 0.2826 \\
\hline $\begin{array}{c}\text { Kleibergen-Paap F } \\
\text { Stock-Yogo weak ID test critical } \\
\text { values: } 10 \% \text { maximal IV size }\end{array}$ & & $\begin{array}{c}8887.539 \\
16.38\end{array}$ & \\
\hline
\end{tabular}

Notes: This table reports the 2SLS analysis regression results using an instrumental variable approach. The

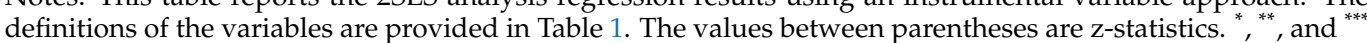
indicate two-tailed significance at the $10 \%, 5 \%$, and $1 \%$ levels, respectively. 
Based on the logic that happiness alleviates financing constraints and in turn promotes green innovation, the impact of happiness on green innovation will be more pronounced when enterprises lack financing channels. In regions with low level of financial development, it is more difficult for enterprises to obtain financing from financial institutions. Regional happiness should therefore play a stronger role in expanding the resource access channels to promote green innovation. We used the marketization index of the Chinese provincial financial industry provided by Wang et al. [102] to measure the level of regional financial development, denoted as FIN. We then examined the effect of financial development on regional happiness and green innovation using the interaction terms. Columns (3) and (4) of Table 8 summarize the regression results. The estimated coefficient of interaction terms was significantly negative, indicating that regional happiness and regional financial development substituted each other; that is, when enterprises were in an unfavorable financing environment, happiness played a more obvious role in promoting green innovation. These results further validate the channels for financing constraints.

Table 6. Alternative measurements for green innovation.

\begin{tabular}{|c|c|c|c|c|}
\hline Variable & $\begin{array}{c}\text { (1) } \\
\text { GINVG1 }\end{array}$ & $\begin{array}{c}\text { (2) } \\
\text { GINVG1 }\end{array}$ & $\begin{array}{c}\text { (3) } \\
\text { GINVG2 }\end{array}$ & $\begin{array}{c}\text { (4) } \\
\text { GINVG2 }\end{array}$ \\
\hline HAPP_DIS & $\begin{array}{c}0.022^{* * *} \\
(5.89)\end{array}$ & & $\begin{array}{c}0.015^{* * *} \\
(6.20)\end{array}$ & \\
\hline HAPP & & $\begin{array}{c}0.149^{* * *} \\
(6.11)\end{array}$ & & $\begin{array}{c}0.112^{* * *} \\
(6.84)\end{array}$ \\
\hline SIZE & $\begin{array}{c}0.294^{* * *} \\
(39.94)\end{array}$ & $\begin{array}{c}0.293^{* * *} \\
(39.87)\end{array}$ & $\begin{array}{c}0.189^{* * *} \\
(38.14)\end{array}$ & $\begin{array}{c}0.188^{* * *} \\
(38.08)\end{array}$ \\
\hline LEV & $\begin{array}{c}0.245^{* * *} \\
(4.96)\end{array}$ & $\begin{array}{c}0.242^{* * *} \\
(4.92)\end{array}$ & $\begin{array}{l}-0.025 \\
(-0.75)\end{array}$ & $\begin{array}{l}-0.027 \\
(-0.80)\end{array}$ \\
\hline ROA & $\begin{array}{l}0.156 \\
(0.96)\end{array}$ & $\begin{array}{l}0.160 \\
(0.98)\end{array}$ & $\begin{array}{l}-0.207^{*} \\
(-1.90)\end{array}$ & $\begin{array}{l}-0.206^{*} \\
(-1.88)\end{array}$ \\
\hline GROWTH & $\begin{array}{c}-0.041^{* *} \\
(-2.17)\end{array}$ & $\begin{array}{c}-0.041^{* *} \\
(-2.17)\end{array}$ & $\begin{array}{c}-0.031^{* *} \\
(-2.44)\end{array}$ & $\begin{array}{c}-0.031^{* *} \\
(-2.44)\end{array}$ \\
\hline SHR1 & $\begin{array}{c}-0.141^{* * *} \\
(-2.77)\end{array}$ & $\begin{array}{c}-0.141^{* * *} \\
(-2.77)\end{array}$ & $\begin{array}{c}-0.131^{* * *} \\
(-3.83)\end{array}$ & $\begin{array}{c}-0.132^{* * *} \\
(-3.85)\end{array}$ \\
\hline INDEP & $\begin{array}{l}0.168 \\
(1.23)\end{array}$ & $\begin{array}{l}0.159 \\
(1.16)\end{array}$ & $\begin{array}{c}0.250^{* * *} \\
(2.72)\end{array}$ & $\begin{array}{c}0.243^{* * *} \\
(2.65)\end{array}$ \\
\hline MSAHRE & $\begin{array}{l}0.038 \\
(0.84)\end{array}$ & $\begin{array}{l}0.034 \\
(0.74)\end{array}$ & $\begin{array}{l}-0.040 \\
(-1.31)\end{array}$ & $\begin{array}{l}-0.043 \\
(-1.42)\end{array}$ \\
\hline SOE & $\begin{array}{l}0.019 \\
(1.02)\end{array}$ & $\begin{array}{l}0.016 \\
(0.86)\end{array}$ & $\begin{array}{c}0.047^{* * *} \\
(3.69)\end{array}$ & $\begin{array}{c}0.044^{* * *} \\
(3.53)\end{array}$ \\
\hline DUAL & $\begin{array}{c}-0.037^{* *} \\
(-2.13)\end{array}$ & $\begin{array}{c}-0.036^{* *} \\
(-2.10)\end{array}$ & $\begin{array}{l}0.002 \\
(0.15)\end{array}$ & $\begin{array}{l}0.002 \\
(0.20)\end{array}$ \\
\hline CASH & $\begin{array}{l}-0.149 \\
(-1.18)\end{array}$ & $\begin{array}{l}-0.141 \\
(-1.12)\end{array}$ & $\begin{array}{l}0.043 \\
(0.51)\end{array}$ & $\begin{array}{l}0.049 \\
(0.57)\end{array}$ \\
\hline PPE & $\begin{array}{c}-0.468^{* * *} \\
(-8.07)\end{array}$ & $\begin{array}{c}-0.467^{* * *} \\
(-8.05)\end{array}$ & $\begin{array}{c}-0.380^{* * *} \\
(-9.73)\end{array}$ & $\begin{array}{c}-0.378^{* * *} \\
(-9.69)\end{array}$ \\
\hline RDI & $\begin{array}{c}4.692^{* * *} \\
(8.32)\end{array}$ & $\begin{array}{c}4.767^{* * *} \\
(8.44)\end{array}$ & $\begin{array}{c}4.452^{* * *} \\
(11.73)\end{array}$ & $\begin{array}{c}4.526^{* * *} \\
(11.90)\end{array}$ \\
\hline GDP & $\begin{array}{c}0.055^{* * * *} \\
(4.94)\end{array}$ & $\begin{array}{c}0.051^{* * *} \\
(4.60)\end{array}$ & $\begin{array}{c}0.033^{* * *} \\
(4.42)\end{array}$ & $\begin{array}{c}0.030^{* * *} \\
(4.03)\end{array}$ \\
\hline Constant & $\begin{array}{c}-6.502^{* * *} \\
(-30.66)\end{array}$ & $\begin{array}{c}-6.569^{* * *} \\
(-31.03)\end{array}$ & $\begin{array}{c}-4.478^{* * *} \\
(-31.39)\end{array}$ & $\begin{array}{c}-4.525^{* * *} \\
(-31.78)\end{array}$ \\
\hline YEAR & Yes & Yes & Yes & Yes \\
\hline IND & Yes & Yes & Yes & Yes \\
\hline Obs. & 14613 & 14613 & 14613 & 14613 \\
\hline Adj. $R^{2}$ & 0.273 & 0.274 & 0.194 & 0.195 \\
\hline
\end{tabular}

Notes: This table provides the results of altering measures of the dependent variables. The definitions of the variables are provided in Table 1 . The values between parentheses are t-statistics. ${ }^{*},{ }^{*}$, and ${ }^{* * *}$ indicate two-tailed significance at the $10 \%, 5 \%$, and $1 \%$ levels, respectively. 
Table 7. Measure of regional happiness based on an analysis of social media sentiment.

\begin{tabular}{|c|c|c|}
\hline Variable & $\begin{array}{c}\text { (1) } \\
\text { GINOV1 }\end{array}$ & $\begin{array}{c}\text { (2) } \\
\text { GINOV1 }\end{array}$ \\
\hline HAPPS1 & $\begin{array}{c}0.784^{* *} \\
(2.28)\end{array}$ & \\
\hline HAPPS2 & & $\begin{array}{c}0.731 * \\
(1.70)\end{array}$ \\
\hline SIZE & $\begin{array}{c}0.438^{* * *} \\
(49.56)\end{array}$ & $\begin{array}{c}0.438^{* * *} \\
(49.54)\end{array}$ \\
\hline LEV & $\begin{array}{l}0.046 \\
(0.80)\end{array}$ & $\begin{array}{l}0.046 \\
(0.79)\end{array}$ \\
\hline ROA & $\begin{array}{c}0.620^{* * *} \\
(3.21)\end{array}$ & $\begin{array}{c}0.619^{* * * *} \\
(3.20)\end{array}$ \\
\hline GROWTH & $\begin{array}{l}-0.009 \\
(-0.42)\end{array}$ & $\begin{array}{l}-0.009 \\
(-0.41)\end{array}$ \\
\hline SHR1 & $\begin{array}{c}-0.207^{* * *} \\
(-3.43)\end{array}$ & $\begin{array}{c}-0.207^{* * *} \\
(-3.43)\end{array}$ \\
\hline INDEP & $\begin{array}{l}0.155 \\
(0.97)\end{array}$ & $\begin{array}{l}0.157 \\
(0.98)\end{array}$ \\
\hline MSAHRE & $\begin{array}{l}0.051 \\
(0.97)\end{array}$ & $\begin{array}{l}0.050 \\
(0.94)\end{array}$ \\
\hline SOE & $\begin{array}{c}0.065^{* * *} \\
(2.90)\end{array}$ & $\begin{array}{c}0.064^{* * *} \\
(2.86)\end{array}$ \\
\hline DUAL & $\begin{array}{l}-0.011 \\
(-0.52)\end{array}$ & $\begin{array}{l}-0.011 \\
(-0.53)\end{array}$ \\
\hline $\mathrm{CASH}$ & $\begin{array}{c}-0.313^{* *} \\
(-2.12)\end{array}$ & $\begin{array}{l}-0.311 \\
(-2.11)\end{array}$ \\
\hline PPE & $\begin{array}{c}-0.550^{* * *} \\
(-7.98)\end{array}$ & $\begin{array}{c}-0.550^{* * *} \\
(-7.98)\end{array}$ \\
\hline RDI & $\begin{array}{c}0.069^{* * *} \\
(5.04)\end{array}$ & $\begin{array}{c}0.071^{* * *} \\
(5.21)\end{array}$ \\
\hline GDP & $\begin{array}{c}6.206^{* * *} \\
(8.33)\end{array}$ & $\begin{array}{c}5.966^{* * *} \\
(8.09)\end{array}$ \\
\hline Constant & $\begin{array}{c}-9.970 \\
(-34.42)\end{array}$ & $\begin{array}{c}-9.955^{* * *} \\
(-31.36)\end{array}$ \\
\hline YEAR & Yes & Yes \\
\hline IND & Yes & Yes \\
\hline Obs. & 14505 & 14505 \\
\hline Adj. $R^{2}$ & 0.323 & 0.323 \\
\hline
\end{tabular}

Notes: This table provides the results of altering measures of the independent variables. The definitions of the variables are provided in Table 1 . The values between parentheses are t-statistics. ${ }^{*},{ }^{* *}$, and ${ }^{* * *}$ indicate two-tailed significance at the $10 \%, 5 \%$, and $1 \%$ levels, respectively.

\subsection{Further Analysis}

Research shows that political connections can provide a significant resource boost for a company. For example, Faccio et al. [103] have presented evidence that politically connected enterprises are more likely to be bailed out when facing financial difficulties than those that are not politically connected. Chan et al. [104] found that Chinese listed companies with political connections seemed to have no financing constraints. These enterprises appeared to have easier access to external credit and explicit preferential treatment, or they may be perceived by lenders as having an implicit government guarantee. Regional happiness promotes the development of regional social networks, thus providing more abundant resource channels for enterprises and compared with politically connected enterprises, enterprises that are not politically connected have a greater demand for green innovation resources through social networks. Therefore, we expected regional happiness to play a more significant role in promoting green innovation in enterprises with no political connections. We defined a dummy variable, PC, which took 1 if the enterprise was politically connected, and 0 otherwise. We added the interaction terms of PC and the happiness 
variables to the regression. As can be seen from the results shown in Table 9, the estimated coefficients of interaction terms were all significantly negative, which means that regional happiness can play a stronger role in promoting green innovation in enterprises without political connections.

Table 8. Discussions of mechanism: financing constraint channel.

\begin{tabular}{|c|c|c|c|c|}
\hline Variable & $\begin{array}{l}\text { (1) } \\
\mathrm{KZ}\end{array}$ & $\begin{array}{c}(2) \\
W W\end{array}$ & $\begin{array}{c}\text { (3) } \\
\text { GINOV1 }\end{array}$ & $\begin{array}{c}\text { (4) } \\
\text { GINOV2 }\end{array}$ \\
\hline FIN & & & $\begin{array}{c}0.003^{* * *} \\
(2.65)\end{array}$ & $\begin{array}{l}0.002^{*} \\
(1.69)\end{array}$ \\
\hline HAPP_DIS $\times$ FIN & & & $\begin{array}{c}-0.002^{* * *} \\
(-3.16)\end{array}$ & $\begin{array}{c}-0.001^{* * *} \\
(-3.03)\end{array}$ \\
\hline HAPP_DIS & $\begin{array}{l}-0.009^{*} \\
(-1.84)\end{array}$ & $\begin{array}{c}-0.0004^{* * *} \\
(-3.42)\end{array}$ & $\begin{array}{c}0.029^{* * *} \\
(6.53)\end{array}$ & $\begin{array}{c}0.027^{* * *} \\
(6.91)\end{array}$ \\
\hline SIZE & $\begin{array}{l}-0.261^{* * *} \\
(-28.04)\end{array}$ & $\begin{array}{l}-0.046^{* * *} \\
(-222.99)\end{array}$ & $\begin{array}{l}0.427^{* * *} \\
(50.85)\end{array}$ & $\begin{array}{l}0.374^{* * *} \\
(50.81)\end{array}$ \\
\hline LEV & $\begin{array}{l}5.760^{* * *} \\
(93.05)\end{array}$ & $\begin{array}{c}0.017^{* * *} \\
(12.40)\end{array}$ & $\begin{array}{l}0.064 \\
(1.16)\end{array}$ & $\begin{array}{l}-0.084 \\
(-1.72)\end{array}$ \\
\hline ROA & $\begin{array}{l}-3.893^{* * *} \\
(-18.81)\end{array}$ & $\begin{array}{l}-0.183^{* * *} \\
(-39.50)\end{array}$ & $\begin{array}{c}0.618^{* * *} \\
(3.35)\end{array}$ & $\begin{array}{c}0.381^{* *} \\
(2.36)\end{array}$ \\
\hline GROWTH & $\begin{array}{l}-0.621^{* * *} \\
(-25.90)\end{array}$ & $\begin{array}{l}-0.035^{* * *} \\
(-65.57)\end{array}$ & $\begin{array}{l}-0.010 \\
(-0.47)\end{array}$ & $\begin{array}{l}-0.014 \\
(-0.74)\end{array}$ \\
\hline SHR1 & $\begin{array}{l}-0.687^{* * *} \\
(-10.76)\end{array}$ & $\begin{array}{c}-0.006^{* * *} \\
(-4.44)\end{array}$ & $\begin{array}{c}-0.212^{* * *} \\
(-3.69)\end{array}$ & $\begin{array}{c}-0.253^{* * *} \\
(-5.02)\end{array}$ \\
\hline INDEP & $\begin{array}{c}0.851^{* * *} \\
(5.00)\end{array}$ & $\begin{array}{c}0.019^{* * *} \\
(4.87)\end{array}$ & $\begin{array}{l}0.193 \\
(1.26)\end{array}$ & $\begin{array}{c}0.330^{* *} \\
(2.46)\end{array}$ \\
\hline MSAHRE & $\begin{array}{l}-0.881^{* * *} \\
(-15.38)\end{array}$ & $\begin{array}{c}-0.012^{* * *} \\
(-9.01)\end{array}$ & $\begin{array}{l}0.017 \\
(0.33)\end{array}$ & $\begin{array}{l}-0.076 \\
(-1.71)\end{array}$ \\
\hline SOE & $\begin{array}{l}0.008 \\
(0.36)\end{array}$ & $\begin{array}{c}0.001^{* *} \\
(2.55)\end{array}$ & $\begin{array}{c}0.067^{* * *} \\
(3.13)\end{array}$ & $\begin{array}{c}0.094^{* * *} \\
(4.98)\end{array}$ \\
\hline DUAL & $\begin{array}{c}-0.070^{* * *} \\
(-3.20)\end{array}$ & $\begin{array}{c}0.00001 \\
(0.02)\end{array}$ & $\begin{array}{l}-0.012 \\
(-0.62)\end{array}$ & $\begin{array}{l}0.022 \\
(1.30)\end{array}$ \\
\hline $\mathrm{CASH}$ & $\begin{array}{c}-14.107^{* * *} \\
(-88.85)\end{array}$ & $\begin{array}{l}-0.096^{* * *} \\
(-26.98)\end{array}$ & $\begin{array}{l}-0.311 \\
(-2.21)\end{array}$ & $\begin{array}{l}-0.080 \\
(-0.65)\end{array}$ \\
\hline PPE & $\begin{array}{l}1.955^{* * *} \\
(27.00)\end{array}$ & $\begin{array}{c}0.011^{* * *} \\
(6.54)\end{array}$ & $\begin{array}{c}-0.548^{* * *} \\
(-8.40)\end{array}$ & $\begin{array}{l}-0.602^{* * *} \\
(-10.51)\end{array}$ \\
\hline RDI & $\begin{array}{c}3.015^{* * *} \\
(4.29)\end{array}$ & $\begin{array}{l}0.031 \\
(1.95)\end{array}$ & $\begin{array}{c}6.313^{* * *} \\
(9.88)\end{array}$ & $\begin{array}{c}6.429^{* * *} \\
(11.47)\end{array}$ \\
\hline GDP & $\begin{array}{l}0.020 \\
(1.44)\end{array}$ & $\begin{array}{c}-0.002^{* * *} \\
(-6.31)\end{array}$ & $\begin{array}{c}0.060^{* * *} \\
(4.40)\end{array}$ & $\begin{array}{c}0.053^{* * *} \\
(4.43)\end{array}$ \\
\hline Constant & $\begin{array}{l}3.701^{* * *} \\
(14.48)\end{array}$ & $\begin{array}{c}0.038^{* * *} \\
(6.68)\end{array}$ & $\begin{array}{c}-9.357^{* * *} \\
(-38.73)\end{array}$ & $\begin{array}{c}-8.401^{* * *} \\
(-39.65)\end{array}$ \\
\hline YEAR & Yes & Yes & Yes & Yes \\
\hline IND & Yes & Yes & Yes & Yes \\
\hline Obs. & 15610 & 15610 & 15610 & 15610 \\
\hline Adj. $R^{2}$ & 0.320 & 0.319 & 0.283 & 0.283 \\
\hline
\end{tabular}

Notes: This table reports the results of testing the financing constraint channel. The definitions of the variables are provided in Table 1 . The values between parentheses are t-statistics. ${ }^{*},{ }^{* *}$, and ${ }^{* * *}$ indicate two-tailed significance at the $10 \%, 5 \%$, and $1 \%$ levels, respectively.

Table 9. Regional happiness, political connections, and green innovation.

\begin{tabular}{|c|c|c|c|c|}
\hline Variable & $\begin{array}{c}\text { (1) } \\
\text { GINOV1 }\end{array}$ & $\begin{array}{c}(2) \\
\text { GINOV2 }\end{array}$ & $\begin{array}{c}\text { (3) } \\
\text { GINOV1 }\end{array}$ & $\begin{array}{c}\text { (4) } \\
\text { GINOV2 }\end{array}$ \\
\hline HAPP_DIS & $\begin{array}{c}0.040^{* * *} \\
(7.34)\end{array}$ & $\begin{array}{c}0.037^{* * *} \\
(7.85)\end{array}$ & & \\
\hline HAPP_DIS $\times$ PC & $\begin{array}{c}-0.024^{* * *} \\
(-2.83)\end{array}$ & $\begin{array}{c}-0.026^{* * *} \\
(-3.41)\end{array}$ & & \\
\hline HAPP & & & $\begin{array}{c}0.231^{* * *} \\
(6.43)\end{array}$ & $\begin{array}{c}0.209^{* * *} \\
(6.56)\end{array}$ \\
\hline $\mathrm{HAPP} \times \mathrm{PC}$ & & & $\begin{array}{c}-0.118^{* *} \\
(-2.09)\end{array}$ & $\begin{array}{c}-0.121 \\
(-2.41)\end{array}$ \\
\hline PC & $\begin{array}{c}0.030^{*} \\
(1.68)\end{array}$ & $\begin{array}{l}0.009 \\
(0.59)\end{array}$ & $\begin{array}{c}0.043^{* *} \\
(2.25)\end{array}$ & $\begin{array}{l}0.022 \\
(1.31)\end{array}$ \\
\hline SIZE & $\begin{array}{c}0.439^{* * *} \\
(53.21)\end{array}$ & $\begin{array}{c}0.388^{* * *} \\
(53.12)\end{array}$ & $\begin{array}{c}0.438^{* * *} \\
(53.13)\end{array}$ & $\begin{array}{c}0.388^{* * *} \\
(53.02)\end{array}$ \\
\hline
\end{tabular}


Table 9. Cont.

\begin{tabular}{|c|c|c|c|c|}
\hline Variable & $\begin{array}{c}\text { (1) } \\
\text { GINOV1 }\end{array}$ & $\begin{array}{c}(2) \\
\text { GINOV2 }\end{array}$ & $\begin{array}{c}\text { (3) } \\
\text { GINOV1 }\end{array}$ & $\begin{array}{c}\text { (4) } \\
\text { GINOV2 }\end{array}$ \\
\hline LEV & $\begin{array}{l}0.041 \\
(0.77)\end{array}$ & $\begin{array}{l}-0.091 \\
(-1.93)\end{array}$ & $\begin{array}{l}0.037 \\
(0.68)\end{array}$ & $\begin{array}{c}-0.096 \\
(-2.02)\end{array}$ \\
\hline ROA & $\begin{array}{c}0.287^{* *} \\
(2.42)\end{array}$ & $\begin{array}{l}0.142 \\
(1.35)\end{array}$ & $\begin{array}{c}0.282^{* *} \\
(2.37)\end{array}$ & $\begin{array}{l}0.137 \\
(1.30)\end{array}$ \\
\hline GROWTH & $\begin{array}{l}-0.000 \\
(-0.86)\end{array}$ & $\begin{array}{l}-0.001 \\
(-1.13)\end{array}$ & $\begin{array}{l}-0.000 \\
(-0.84)\end{array}$ & $\begin{array}{l}-0.001 \\
(-1.11)\end{array}$ \\
\hline SHR1 & $\begin{array}{c}-0.231^{* * *} \\
(-3.99)\end{array}$ & $\begin{array}{c}-0.267^{* * *} \\
(-5.19)\end{array}$ & $\begin{array}{c}-0.230^{* * *} \\
(-3.97)\end{array}$ & $\begin{array}{c}-0.266^{* * *} \\
(-5.16)\end{array}$ \\
\hline INDEP & $\begin{array}{l}0.221 \\
(1.47)\end{array}$ & $\begin{array}{c}0.295^{* *} \\
(2.21)\end{array}$ & $\begin{array}{l}0.206 \\
(1.37)\end{array}$ & $\begin{array}{c}0.280^{* *} \\
(2.10)\end{array}$ \\
\hline MSAHRE & $\begin{array}{l}0.012 \\
(0.23)\end{array}$ & $\begin{array}{c}-0.081 \\
(-1.78)\end{array}$ & $\begin{array}{l}0.008 \\
(0.16)\end{array}$ & $\begin{array}{c}-0.084 \\
(-1.84)\end{array}$ \\
\hline SOE & $\begin{array}{c}0.058^{* * *} \\
(2.66)\end{array}$ & $\begin{array}{c}0.085^{* * *} \\
(4.40)\end{array}$ & $\begin{array}{c}0.054^{* *} \\
(2.49)\end{array}$ & $\begin{array}{c}0.082^{* * *} \\
(4.22)\end{array}$ \\
\hline DUAL & $\begin{array}{l}-0.001 \\
(-0.07)\end{array}$ & $\begin{array}{l}0.032 \text { * } \\
(1.79)\end{array}$ & $\begin{array}{l}-0.001 \\
(-0.03)\end{array}$ & $\begin{array}{c}0.033^{*} \\
(1.83)\end{array}$ \\
\hline $\mathrm{CASH}$ & $\begin{array}{l}-0.161 \\
(-1.28)\end{array}$ & $\begin{array}{l}0.002 \\
(0.02)\end{array}$ & $\begin{array}{l}-0.150 \\
(-1.19)\end{array}$ & $\begin{array}{l}0.013 \\
(0.11)\end{array}$ \\
\hline PPE & $\begin{array}{c}-0.587^{* * *} \\
(-9.04)\end{array}$ & $\begin{array}{c}-0.637^{* * *} \\
(-11.06)\end{array}$ & $\begin{array}{c}-0.589^{* * * *} \\
(-9.06)\end{array}$ & $\begin{array}{c}-0.640^{* * *} \\
(-11.10)\end{array}$ \\
\hline RDI & $\begin{array}{c}6.192^{* * *} \\
(9.61)\end{array}$ & $\begin{array}{c}6.409^{* * *} \\
(11.22)\end{array}$ & $\begin{array}{c}6.239^{* * *} \\
(9.66)\end{array}$ & $\begin{array}{c}6.430^{* * *} \\
(11.23)\end{array}$ \\
\hline GDP & $\begin{array}{c}0.077^{* * *} \\
(6.18)\end{array}$ & $\begin{array}{c}0.064^{* * *} \\
(5.75)\end{array}$ & $\begin{array}{c}0.073^{* * *} \\
(5.82)\end{array}$ & $\begin{array}{c}0.060^{* * *} \\
(5.39)\end{array}$ \\
\hline Constant & $\begin{array}{c}-9.699^{* * *} \\
(-42.67)\end{array}$ & $\begin{array}{l}-8.811^{* * *} \\
(-43.72)\end{array}$ & $\begin{array}{c}-9.645^{* * *} \\
(-42.44)\end{array}$ & $\begin{array}{c}-8.762^{* * *} \\
(-43.48)\end{array}$ \\
\hline YEAR & Yes & Yes & Yes & Yes \\
\hline IND & Yes & Yes & Yes & Yes \\
\hline Obs. & 15476 & 15476 & 15476 & 15476 \\
\hline Adj. $R^{2}$ & 0.329 & 0.293 & 0.328 & 0.292 \\
\hline
\end{tabular}

Notes: This table reports the impact of political connection on the effect of regional happiness on corporate green innovation. The definitions of the variables are provided in Table 1 . The values between parentheses are t-statistics. ${ }^{*},{ }^{* *}$, and ${ }^{* * *}$ indicate two-tailed significance at the $10 \%, 5 \%$, and $1 \%$ levels, respectively.

\section{Discussion}

In recent decades, a series of instances of excessive pollution globally has highlighted the need for green innovation and economic transformation. As the carrying capacity of the ecological environment approaches its limit, implementing green innovation by enterprises has become an increasingly important way to ensure a balanced development between ecological environmental protection and economic growth. In this context, the promotion of enterprise green innovation has attracted extensive attention from scholars. Several studies have shown that formal institutional constraints dominated by environmental regulations are effective tools for the government to stimulate corporate green innovation; however, based on the literature and practical observations, it is shown that in some regions with the same institutional background, there will be significant differences in the level of green innovation of enterprises, which cannot be explained by the characteristics of individual companies or formal institutions. Regional culture can influence the green innovation process of enterprises by shaping the external environment, and informal institutions, such as culture, may also be a key factor influencing green innovation, but how corporate green innovation is affected by the informal institutional environment has not received widespread attention. According to Chuluun and Graham [8] and Heo and Hou [9], happiness is considered to be an important regional culture that determines economic development and social progress in addition to legal and formal institutions and is an alternative system to formal institutions. This study attempts to fill gaps in the existing research by examining the impact of regional happiness on corporate green innovation.

This study uses the data of Chinese listed companies as samples to construct city-level happiness data to test and explore the influence of regional happiness on corporate green innovation. If regional happiness is conducive to the green innovation of enterprises, the 
output of green innovation of enterprises in regions with high happiness levels will increase when other relevant factors and endogenous problems are considered. Our empirical results support the hypothesis that regional happiness increases the number of green patents and promotes high-quality green innovation. The results hold even after accounting for endogeneity and measurement errors. This result is consistent with Pan's view that the informal system is the external driving force of enterprise green innovation [1]. As China is in a period of economic transition, there are weak links in the formal system, promoting the informal system to play an important role in economic operations. By investigating the mechanism of regional happiness in green innovation, we found that happiness has an impact on green innovation through a financing constraint mechanism. External financing is an important source of funds for enterprises to carry out green innovation, but as a high-risk investment activity, green innovation has serious information asymmetry and agency risk, which restricts enterprises from obtaining sufficient external financing at a low cost for continuous financial support of green innovation activities. Regional happiness, as an informal system, plays a resource effect role by promoting rich social networks and improving the financing of green innovation activities. By introducing the interaction term between formal institutions and regional happiness, we found that regional happiness has a more significant effect on the improvement of green innovation performance for enterprises with low financial development levels or a lack of political connections. When enterprises lacked resource channels or external financing systems lack effectiveness, there was a substitution effect between the informal and formal institutions of regional happiness.

Two concurrent studies have examined the relationship between regional happiness and enterprise economic activities [89]. Heo and Hou [9] provide international evidence that happiness plays a vital role in promoting corporate innovation; however, their research did not explore the relationship between regional happiness and enterprise innovation at the micro-level. Unlike Heo and Hou [9], we focused on happiness at the city level. A cross-city study conducted by Chuluun and Graham [8] shows that the cities' happiness levels promote the investment behaviors of local enterprises. The financing constraint mechanism of regional happiness was not, however, discussed or explained by Chuluun and Graham [8]. Consequently, this study takes financing constraints as a new perspective, analyzes the mechanism behind the effect of happiness on corporate green innovation, investigates the micro path of regional happiness on green innovation, and analyzes the relationship between informal institutions and environmental sustainability. We found that happiness can significantly improve firms' green innovation performance by alleviating their financing constraints and providing resource support.

The extant literature recognizes the role of positive emotions in promoting proenvironment behaviors, with empirical evidence establishing an encouraging link between subjective happiness and such behavior, including multi-country analyses. Positive correlations between personal happiness and pro-environmental behaviors that include recycling, green purchasing, or reducing consumption have been reported among Swedish adult samples [105], American teenagers and adults [106], British households [107], and German adults [108]; however, environmental behavior is a multilevel concept, while the literature has largely focused on pro-environmental behavior among individuals, e.g., green purchasing and reducing consumption. Pro-environmental behavior includes not only the responsible consumption habits of individuals, but also the practices and attitudes of corporations towards green policies. To make progress, we continue to conduct an empirical analysis and study the relationship between happiness and corporate green innovation, as well as the internal mechanism of this connection. Cross-country studies prove that the positive relationship between happiness and pro-environmental behavior is replicated at the national level. Welsch and Kuhling [109] found a positive correlation between life satisfaction and the green self-image in European countries. Welsch and Kuhling [110] also included both developed and developing countries in their sample and found that national life satisfaction was positively correlated with citizens' environmentally friendly behavior; however, the implications of cross-country happiness research on policy-making 
are limited. In particular, less-developed countries are often unable to improve their social institutions quickly or emulate the policies of countries that have a high level of happiness. Our study demonstrates that differences in happiness among different regions within a country can explain corporate green innovation. This means that within a country, where similar institutions and degrees of freedom exist, less happy regions can more easily adopt policies that have been formulated in happy regions to facilitate environmentally friendly corporate behaviors, thus providing a feasible way to achieve a win-win situation from a policy perspective.

This study extends the literature on the determinants of corporate green innovation by identifying the role of regional happiness. Our findings complement Pan et al.'s research on the determinants of corporate green innovation in informal institutions [1]. Further, this study enriches the research on the economic impact of informal institutions. As deep-seated influencers of economic development, social and cultural factors are the key research fields of the economic development theory [111]. Additionally, in recent years, some scholars have investigated the effect of cultural factors at the micro-level from the perspective of informal institutions, but most of them focus on the Western context and use transnational data to compare the influence of cultural characteristics of different countries on enterprise behavior. A few studies have mainly focused on specific developed countries [6]. This study adopts a single country sample, which not only helps to control the interference of institutional differences in different countries on the empirical conclusions, but also contributes empirical evidence from the transitional economic situation to the emerging research field of "culture and finance".

Our study involves literature on the economic consequences of happiness. Happiness is a crucial concept, attracting the interpretation of philosophy, psychology, sociology, economics, culture, and other disciplines. Regional happiness has economic influence beyond social significance, which verifies the view that happiness is an important variable affecting behavioral decision-making in psychology literature. This study found that regional happiness affects a company's environmental responsibility. Therefore, actively paying attention to the social and cultural characteristics of an enterprise's location is conducive to an in-depth understanding of the decision-making mode of the enterprise, which can provide an effective reference for stakeholders to evaluate the operating risk and investment value of the enterprise.

\section{Conclusions}

Actively responding to the challenges brought on by climate change and implementing low-carbon green transformation in economic and social development is of great significance, both theoretically and practically. Regional happiness has a resource effect by promoting rich social networks and plays a positive role in corporate green innovation. This study attempts to clarify the impact path of regional happiness on corporate green innovation and empirically tests the impact of local happiness on corporate green innovation. In this study, a social media sentiment analysis was used to re-measure local happiness to enhance the robustness of the research results. The results show that regional happiness has a positive impact on green innovation, that is, regional happiness has a green innovation incentive effect. The results hold even after accounting for endogeneity and measurement errors. The mechanism test shows that regional happiness can promote green innovation by alleviating financing constraints. Regional happiness promotes a rich social network, and the resource effect improves the financing situation of green innovation activities, thus promoting the improvement of green innovation performance. For enterprises in areas with higher financial development, the positive effect of regional happiness on green innovation decreases significantly, indicating that informal and formal institutions have a substitution effect on corporate green innovation. Further analysis shows that for enterprises lacking political connections, regional happiness plays a more significant role in promoting green innovation, indicating that in the absence of financing convenience, regional happiness plays a substitute role for implicit government guarantees through rich resource channels. 
This study has important implications for policymakers. First, regional happiness helps to promote the formation of social support networks and has an incentive effect on corporate green innovation. The green innovation incentive effect of happiness shows that a non-mandatory mechanism plays an important role in encouraging green innovation. Shifting from traditional economic deterrence to a psychosocial approach to promoting green innovation in business will help to reduce regulatory and enforcement costs. In addition to environmental regulations and other formal institutional factors, regional happiness is also an important driving force for green innovation. Therefore, in addition to relying on the administrative power of the government, building an external environment that promotes green innovation can pay attention to the positive psychological resources of the region. Education should not only emphasize imparting knowledge but should also cultivate self-confidence, optimism, and positive psychological characteristics. Second, this study shows that an important mechanism for regional happiness in corporate green innovation is the resource effect. Regional happiness can play a greater role when the level of regional financial development is low, and enterprises lack political connections and regional happiness can compensate for the deficiency of external constraint mechanisms. It is therefore necessary to consider and apply both formal and informal institutional factors comprehensively to promote corporate green innovation. Besides relying on the force of formal institutions, the government should also pay attention to creating positive social values and an environment that is conducive to a moral atmosphere.

This has crucial implications for economic entities. First, regional happiness is a precious resource that enterprises should attach great importance to and actively develop and utilize. Enterprises need to interact with the external environment and absorb and reserve resource channels to give full play to the value of regional happiness. This will help enterprises achieve a better green innovation ability and output. Secondly, to promote green innovation by using regional happiness, enterprises need to establish an advanced management system and cultivate an open and inclusive organizational culture to effectively interact with the external cultural environment. Finally, green innovation is the most important means for enterprises to achieve long-term competitiveness. Since regional happiness can ease financing constraints and support green innovation, enterprises can take the happiness level of a region as a reference factor when selecting sites.

This study has four limitations. First, in terms of variable measurement, this study only measures happiness at a city level, which weakens the validity of the research conclusion to some extent. Second, green innovation is not divided into green product innovation and green process innovation in detail; however, the classification of green innovation is not discussed in this study. Third, the data sources are not abundant. The relevant data and materials in this study were mainly from the annual reports of listed companies, excluding interim reports, quarterly reports, and interim reports. Last, this study is based on the sample of a single country, and the results are not sufficiently universal.

Future research can be conducted on the following aspects. Firstly, obtaining more accurate regional happiness data can help improve the reliability of research, and future research can investigate the impact of regional happiness on the behavior and decision making of listed companies based on more abundant data sources. Secondly, green innovation can be divided into green product innovation and green process innovation. The different effects and mechanisms of happiness on green product innovation and green process innovation deserve further study. Finally, due to differences in the economic environment and culture, whether the effect of regional happiness on corporate-responsible behavior exists in other countries and regions is also worthy of further study.

Author Contributions: Conceptualization, D.L.; methodology, D.L.; software, D.L.; validation, D.L.; formal analysis, D.L.; investigation, D.L.; resources, D.L.; data curation, D.L.; writing, D.L.; project administration, D.L.; funding acquisition, W.S. All authors have read and agreed to the published version of the manuscript.

Funding: This research was funded by the National Natural Science Foundation of China (71673231). 
Institutional Review Board Statement: Not applicable.

Informed Consent Statement: Not applicable.

Data Availability Statement: The data presented in this study are available upon request from the corresponding author.

Acknowledgments: The authors would like to acknowledge the support provided by Xiamen University, China.

Conflicts of Interest: The authors declare no conflict of interest.

\section{References}

1. Pan, Z.; Liu, L.; Bai, S.; Ma, Q. Can the social trust promote corporate green innovation? Evidence from China. Environ. Sci. Pollut. Res. 2021, 28, 52157-52173. [CrossRef] [PubMed]

2. Hojnik, J.; Ruzzier, M. The driving forces of process eco-innovation and its impact on performance: Insights from Slovenia. J. Clean Prod. 2016, 133, 812-825. [CrossRef]

3. Gavurová, B.; Belás, J.; Valášková, K.; Rigelský, M; Ivanková, V. Relations between infrastructure innovations and tourism spending in developed countries: A macroeconomic perspective. Technol. Econ. Dev. Econ. 2021, 27, 1072-1094. [CrossRef]

4. Amore, M.D.; Bennedsen, M. Corporate governance and green innovation. J. Environ. Econ. Manage. 2016, 75, 54-72. [CrossRef]

5. Driessen, P.H.; Hillebrand, B.; Kok, R.A.; Verhallen, T.M. Green new product development: The pivotal role of product greenness. IEEE Trans. Eng. Manage. 2013, 60, 315-326. [CrossRef]

6. Hilary, G.; Hui, K.W. Does religion matter in corporate decision making in America? J. Financ. Econ. 2009, 93, 455-473. [CrossRef]

7. Granovetter, M. Economic action and social structure: The problem of embeddedness. Am. J. Sociol. 1985, 91, 481-510. [CrossRef]

8. Chuluun, T.; Graham, C. Local happiness and firm behavior: Do firms in happy places invest more? J. Econ. Behav. Organ. 2016, 125, 41-56. [CrossRef]

9. SSRN. Happiness and innovation around the world. Available online: https://papers.ssrn.com/sol3/papers.cfm?abstract_id=3368666 (accessed on 20 January 2022).

10. Brethel-Haurwitz, K.M.; Marsh, A.A. Geographical differences in subjective well-being predict extraordinary altruism. Psychol. Sci. 2014, 25, 762-771. [CrossRef]

11. Layous, K.; Nelson, S.K.; Kurtz, J.L.; Lyubomirsky, S. What triggers prosocial effort? A positive feedback loop between positive activities, kindness, and well-being. J. Posit. Psychol. 2017, 12, 385-398. [CrossRef]

12. Mehl, M.R.; Vazire, S.; Holleran, S.E.; Clark, C.S. Eavesdropping on happiness: Well-being is related to having less small talk and more substantive conversations. Psychol. Sci. 2010, 21, 539-541. [CrossRef]

13. Guven, C. Are happier people better citizens? Kyklos 2011, 64, 178-192. [CrossRef]

14. Xiao, Y.; Liu, X.; Ren, T. Institutional differences in individual wellbeing in China. Sustainability 2022, 14, 721. [CrossRef]

15. Du, M.; Wang, B.; Wu, Y. Sources of China's economic growth: An empirical analysis based on the BML index with green growth accounting. Sustainability 2014, 6, 5983-6004. [CrossRef]

16. The United Nations. China headed towards carbon neutrality by 2060; President Xi Jinping vows to halt new coal plants abroad. Available online: https:/ / news.un.org/en/story/2021/09/1100642 (accessed on 20 January 2022).

17. Przychodzen, J.; Przychodzen, W. Relationships between eco-innovation and financial performance-evidence from publicly traded companies in Poland and Hungary. J. Clean Prod. 2015, 90, 253-263. [CrossRef]

18. Mittal, H. How does the institutional context of an emerging economy shape the innovation trajectory of different types of firms? A case study of India. Ekon. Manaz. Spektrum 2020, 14, 36-51. [CrossRef]

19. Diener, E. Subjective well-being. Psychol. Bull. 1984, 95, 542-575. [CrossRef]

20. Ryff, C.D. Happiness is everything, or is it? Explorations on the meaning of psychological well-being. J. Pers. Soc. Psychol. 1989, 57, 1069-1081. [CrossRef]

21. Diener, E.; Suh, E.M.; Lucas, R.E.; Smith, H.L. Subjective well-being: Three decades of progress. Psychol. Bull. 1999, $125,276$. [CrossRef]

22. Highhouse, S. Well-being: The foundations of hedonic psychology. Pers. Psychol. 2001, 54, 204.

23. Ross, M.; Eyman, A.; Kishchuck, N. Determinants of subjective well-being. In Relative Deprivation and Social Comparison; Olson, J.M., Herman, C.P., Zanna, M.P., Eds.; Psychology Press: Hove, UK, 2005; pp. 79-92.

24. Luthans, F.; Avolio, B.J.; Avey, J.B.; Norman, S.M. Positive psychological capital: Measurement and relationship with performance and satisfaction. Pers. Psychol. 2007, 60, 541-572. [CrossRef]

25. Youssef, M.C.M.; Luthans, F. Psychological capital and well-being. Stress Health 2015, 31, 180-188. [CrossRef] [PubMed]

26. Alesiona, A.; Di, T.R.; Macculloch, R. Inequality and happiness: Are Europeans and Americans different? J. Public Econ. 2004, 88, 2009-2042. [CrossRef]

27. $\mathrm{Ng}, \mathrm{Y}$. Happiness studies: Ways to improve comparability and some public policy implications. Econ. Rec. 2008, 84, 253-266. [CrossRef]

28. Glaeser, E.L.; Resseger, M.; Tobio, K. Inequality in cities. J. Reg. Sci. 2009, 49, 617-646. [CrossRef] 
29. Lawless, N.M.; Lucas, R.E. Predictors of regional well-being: A county level analysis. Soc. Indic. Res. 2010, 101, 341-357. [CrossRef]

30. Florida, R.; Mellander, C.; Rentfrow, P.J. The Happiness of Cities. Reg. Stud. 2013, 47, 613-627. [CrossRef]

31. Oswald, A.J.; Proto, E.; Sgroi, D. Happiness and productivity. J. Labor Econ. 2015, 33, 789-822. [CrossRef]

32. Ifcher, J.; Zarghamee, H. Happiness and time preference: The effect of positive affect in a random-assignment experiment. Am. Econ. Rev. 2011, 101, 3109-3129. [CrossRef]

33. Cohn, M.A.; Fredrickson, B.L.; Brown, S.L.; Mikels, J.A.; Conway, A.M. Happiness unpacked: Positive emotions increase life satisfaction by building resilience. Emotion 2009, 9, 361-368. [CrossRef]

34. Wright, T.A.; Bonett, D.G. Job satisfaction and psychological well-being as nonadditive predictors of workplace turnover. J. Manag. 2007, 33, 141-160. [CrossRef]

35. Nelson, D.W. Feeling good and open-minded: The impact of positive affect on cross cultural empathic responding. J. Posit. Psychol. 2009, 4, 53-63. [CrossRef]

36. Aknin, L.B.; Dunn, E.W.; Norton, M.I. Happiness Runs in a Circular Motion: Evidence for a Positive Feedback Loop between Prosocial Spending and Happiness. J. Happiness Stud. 2011, 13, 347-355. [CrossRef]

37. Diener, E.; Ryan, K. Subjective well-being: A general overview. S. Afr. J. Psychol. 2009, 39, 391-406. [CrossRef]

38. Madrid, H.P.; Patterson, M.G.; Birdi, K.S.; Leiva, P.I.; Kausel, E.E. The role of weekly high-activated positive mood, context, and personality in innovative work behavior: A multilevel and interactional model. J. Organ. Behav. 2014, 35, 234-256. [CrossRef]

39. Usai, A.; Orlando, B.; Mazzoleni, A. Happiness as a Driver of Entrepreneurial Initiative and Innovation Capital. J. Intellect. Cap. 2020, 21, 1229-1255. [CrossRef]

40. Krause, A. Don't worry, be happy? Happiness and reemployment. J. Econ. Behav. Organ. 2013, 96, 1-20. [CrossRef]

41. SSRN. The objective benefits of subjective well-being. Available online: https://papers.ssrn.com/sol3/papers.cfm?abstract_id=2306651 (accessed on 20 January 2022).

42. Roberts, B.W.; Caspi, A.; Moffitt, T.E. Work experiences and personality development in young adulthood. J. Pers. Soc. Psychol. 2003, 84, 582. [CrossRef]

43. Graham, C. The economics of happiness. World Econ. 2005, 6, 41

44. De Neve, J.E.; Oswald, A.J. Estimating the influence of life satisfaction and positive affect on later income using sibling fixed effects. Proc. Natl. Acad. Sci. USA 2012, 109, 19953-19958. [CrossRef]

45. Diva-portal. Reverse the question: Does happiness raise economic output? Evidence from European Value Survey, 1981-2009. Available online: https:/ / www.diva-portal.org/smash/get/diva2:637590/FULLTEXT02.pdf (accessed on 25 January 2022).

46. Boehm, J.K.; Lyubomirsky, S. Does happiness lead to career success? J. Career Assess. 2008, 16, 101-116. [CrossRef]

47. Otrachshenko, V.; Popova, O. Life (dis) satisfaction and the intention to migrate: Evidence from Central and Eastern Europe. J. Soc. Econ. 2014, 48, 40-49. [CrossRef]

48. Howell, R.T.; Kern, M.L.; Lyubomirsky, S. Health benefits: Meta-analytically determining the impact of well-being on objective health outcomes. Health Psychol. Rev. 2007, 1, 83-136. [CrossRef]

49. Boehm, J.K.; Kubzansky, L.D. The heart's content: The association between positive psychological well-being and cardiovascular health. Psychol. Bull. 2012, 138, 655. [CrossRef]

50. Diener, E.; Chan, M.Y. Happy people live longer: Subjective well-being contributes to health and longevity. Appl. Psychol. Health Well Being 2011, 3, 1-43. [CrossRef]

51. Montani, F.; Courcy, F.; Vandenberghe, C. Innovating under stress: The role of commitment and leader-member exchange. J. Bus. Res. 2017, 77, 1-13. [CrossRef]

52. Shalley, C.E.; Zhou, J.; Oldham, G.R. The effects of personal and contextual characteristics on creativity: Where should we go from here? J. Manag. 2004, 30, 933-958. [CrossRef]

53. Galambos, L. Profits of science: The American marriage of business and technology. Science 1994, 265, 687-689. [CrossRef]

54. Foster, C.; Green, K. Greening the innovation process. Bus. Strategy Environ. 2000, 9, 287-303. [CrossRef]

55. Magnusson, T.; Lindström, G.; Berggren, C. Architectural or modular innovation? Managing discontinuous product development in response to challenging environmental performance targets. Int. J. Innov. Manag. 2003, 7, 1-26. [CrossRef]

56. Durana, P.; Valaskova, K.; Vagner, L.; Zadnanova, S.; Podhorska, I.; Siekelova, A. Disclosure of strategic managers' factotum: Behavioral incentives of innovative business. Int. J. Financ. Stud. 2020, 8, 17. [CrossRef]

57. Durana, P.; Zauskova, A.; Vagner, L.; Zadnanova, S. Earnings drivers of Slovak manufacturers: Efficiency assessment of innovation management. Appl. Sci. 2020, 10, 4251. [CrossRef]

58. Kemp, R.; Pearson, P. Final Report MEI Project about Measuring Eco-Innovation; UM Merit: Maastricht, The Netherlands, 2007; Volume 10, pp. 1-120.

59. Clausen, T.H. External knowledge sourcing from innovation cooperation and the role of absorptive capacity: Empirical evidence from Norway and Sweden. Technol. Anal. Strateg. Manage. 2013, 25, 57-70. [CrossRef]

60. Horbach, J. Determinants of environmental innovation-New evidence from German panel data sources. Res. Policy. 2008, 37, 163-173. [CrossRef]

61. Menguc, B.; Auh, S.; Ozanne, L. The interactive effect of internal and external factors on a proactive environmental strategy and its influence on a firm's performance. J. Bus. Ethics 2010, 94, 279-298. [CrossRef] 
62. Handfield, R.; Walton, S.V.; Sroufe, R.; Melnyk, S.A. Applying environmental criteria to supplier assessment: A study in the application of the analytical hierarchy process. Eur. J. Oper. Res. 2002, 141, 70-87. [CrossRef]

63. Chen, Y.S.; Chang, C.H. The determinants of green product development performance: Green dynamic capabilities, green transformational leadership, and green creativity. J. Bus. Ethics 2013, 116, 107-119. [CrossRef]

64. Simpson, D.; Samson, D. Environmental strategy and low waste operations: Exploring complementarities. Bus. Strateg. Environ. 2010, 19, 104-118. [CrossRef]

65. Chatterjee, D.; Grewal, R.; Sambamurthy, V. Shaping up for e-commerce: Institutional enablers of the organizational assimilation of web technologies. MIS Q. 2002, 26, 65-89. [CrossRef]

66. Bansal, P. From issues to actions: The importance of individual concerns and organizational values in responding to natural environmental issues. Organ. Sci. 2003, 14, 510-527. [CrossRef]

67. Rennings, K.; Rammer, C. The Impact of regulation-driven enviromental innovation on innovation success and firm performance Ind. Innov. 2011, 18, 255-283. [CrossRef]

68. Porter, M.E.; Van der Linde, C. Toward a new conception of the environment-competitiveness relationship. J. Econ. Perspect. 1995, 9, 97-118. [CrossRef]

69. Zeng, S.X.; Meng, X.H.; Zeng, R.C.; Tam, C.M.; Tam, V.W.; Jin, T. How Environmental management driving forces affect environmental and economic performance of SMEs: A study in the northern China district. J. Clean Prod. 2011, 19, 1426-1437. [CrossRef]

70. Chen, X.; Yi, N.; Zhang, L.; Li, D. Does institutional pressure foster corporate green innovation? Evidence from China's top 100 companies. J. Clean Prod. 2018, 188, 304-311. [CrossRef]

71. Kneller, R.; Manderson, E. Environmental regulations and innovation activity in UK manufacturing industries. Resour. Energy Econ. 2012, 34, 211-235. [CrossRef]

72. Yuan, Q. How to Restrain Regulatory Capture and Promote Green Innovation in China. An Analysis Based on Evolutionary Game Theory. Sustainability 2021, 13, 9752. [CrossRef]

73. SSRN. Environmental risk and green innovation: Evidence from evacuation spills. Available online: https://papers.ssrn.com/ sol3/papers.cfm?abstract_id=3740551 (accessed on 25 January 2022).

74. Zhang, F.; Zhu, L. Enhancing corporate sustainable development: Stakeholder pressures, organizational learning, and green innovation. Bus. Strategy Environ. 2019, 28, 1012-1026. [CrossRef]

75. Weng, M.; Lin, C. Determinants of green innovation adoption for small and medium-size enterprises (SMES). Afr. J. Bus. Manag. 2011, 5, 9154-9163.

76. Zhang, Y.; Zhang, J.; Cheng, Z. Stock market liberalization and corporate green innovation: Evidence from China. Int. J. Environ. Res. Public Health 2021, 18, 3412. [CrossRef]

77. García-Sánchez, I.M.; Aibar-Guzmán, C.; Aibar-Guzmán, B. The effect of institutional ownership and ownership dispersion on eco-innovation. Technol. Forecast. Soc. Chang. 2020, 158, 120173. [CrossRef]

78. Hu, G.; Wang, X.; Wang, Y. Can the green credit policy stimulate green innovation in heavily polluting enterprises? Evidence from a quasi-natural experiment in China. Energy Econ. 2021, 98, 105134. [CrossRef]

79. Huang, Z.; Liao, G.; Li, Z. Loaning scale and government subsidy for promoting green innovation. Technol. Forecast. Soc. Chang. 2019, 144, 148-156. [CrossRef]

80. Wang, Y.; Zhao, N.; Lei, X.; Long, R. Green Finance Innovation and Regional Green Development. Sustainability 2021, 13, 8230. [CrossRef]

81. Chen, X.; Chen, Z. Can Green Finance Development Reduce Carbon Emissions? Empirical Evidence from 30 Chinese Provinces. Sustainability 2021, 13, 12137. [CrossRef]

82. National Bureau of Economic Research. International evidence on the social context of well-being. Available online: https: / / www.nber.org/papers/w14720 (accessed on 25 January 2022).

83. Smith, C.A.; Lazarus, R.S. Emotion and adaptation. In Handbook of Personality: Theory and Research; Pervin, L.A., Ed.; Guilford: New York, NY, USA, 1990; pp. 609-673.

84. Baron, R.A. Interviewer's Moods and Reactions to Job Applicants:The Influence of Affective States on Applied Social Judgments. J. Appl. Soc. Psychol. 2006, 17, 911-926. [CrossRef]

85. Diener, E.; Seligman, M.E. Very happy people. Psychol. Sci. 2002, 13, 81-84. [CrossRef]

86. Alshaikh, I.Y.; Razzaque, A.; Alalawi, M.S.M. Positive emotion and social capital affect knowledge sharing: Case of the public sector of the Kingdom of Bahrain. In Proceedings of the European, Mediterranean, and Middle Eastern Conference on Information Systems, Coimbra, Portugal, 7-8 September 2017.

87. Lerner, J.S.; Li, Y.; Valdesolo, P.; Kassam, K.S. Emotion and decision making. Annu. Rev. Psychol. 2015, 66, 799-823. [CrossRef]

88. Dunn, J.R.; Schweitzer, M.E. Feeling and Believing: The Influence of Emotion on Trust. J. Pers. Soc. Psychol. 2005, 88, 736-748. [CrossRef]

89. Wernerfelt, B.A. A resource-based view of the firm. Strateg. Manage. J. 1984, 5, 171-180. [CrossRef]

90. Hoff, K.; Stiglitz, J.E. Introduction: Imperfect information and rural credit markets: Puzzles and policy perspectives. World Bank Econ. Rev. 1990, 4, 235-250. [CrossRef]

91. Bhattacharya, S.; Ritter, J.R. Innovation and communication: Signalling with partial disclosure. Rev. Econ. Stud. 1983, 50, 331-346. [CrossRef] 
92. Wurlod, J.; Noailly, J. The impact of green innovation on energy intensity: An empirical analysis for 14 industrial sectors in OECD countries. Energy Econ. 2018, 71, 47-61. [CrossRef]

93. Xiu, Z.; Zhou, Z. Regional happiness, social capital and corporate philanthropic giving. Journal of Management Science 2016, 29, $146-160$.

94. Fowler, J.H.; Christakis, N.A. Dynamic spread of happiness in a large social network: Longitudinal analysis over 20 years in the Framingham Heart Study. BMJ 2008, 337, a2338. [CrossRef]

95. Mulaessa, N.; Lin, L. How do proactive environmental strategies affect green innovation? The Moderating Role of Environmental Regulations and Firm Performance. Int. J. Environ. Res. Public Health 2021, 18, 9083. [CrossRef]

96. Foye, C. The relationship between size of living space and subjective well-being. J. Happiness Stud. 2017, 18, 427-461. [CrossRef]

97. Sock, J.H.; Yogo, M. Testing for weak instruments in linear IV regression. In Identification and Inference for Econometric Models: Essays in Honor of Thomas Rothenberg; Andrews, D.W.K., Stock, J.H., Eds.; Cambridge University Press: Cambridge, UK, 2005; pp. 80-118.

98. Mitchell, L.; Frank, M.R.; Harris, K.D.; Dodds, P.S.; Danforth, C.M. The geography of happiness: Connecting twitter sentiment and expression, demographics, and objective characteristics of place. PLoS ONE 2013, 8, e64417. [CrossRef]

99. Zheng, S.; Wang, J.; Sun, C.; Zhang, X.; Kahn, M.E. Air pollution lowers Chinese urbanites' expressed happiness on social media. Nat. Hum. Behav. 2019, 3, 237-243. [CrossRef]

100. Kaplan, S.N.; Zingales, L. Do investment-cash flow sensitivities provide useful measures of financing constraints? Q. J. Econ. 1997, 112, 169-215. [CrossRef]

101. Whited, T.M.; Wu, G. Financial constraints risk. Rev. Financ. Stud. 2006, 19, 531-559. [CrossRef]

102. Wang, X.; Hu, L.; Fan, G. Marketization Index of China's Provinces: NERI Report 2021; Social Sciences Academic Press: Beijing, China, 2021; p. 276.

103. Faccio, M.; Masulis, R.W.; McConnell, J.J. Political connections and corporate bailouts. J. Financ. 2006, 61, 2597-2635. [CrossRef]

104. Chan, K.S.; Dang, V.Q.T.; Yan, I.K.M. Chinese firms' political connection, ownership, and financing constraints. Econ. Lett. 2012, 115, 164-167. [CrossRef]

105. Kaida, N.; Kaida, K. Pro-environmental behavior correlates with present and future subjective well-being. Environ. Dev. Sustain. 2016, 18, 111-127. [CrossRef]

106. Brown, K.W.; Kasser, T. Are psychological and ecological well-being compatible? The role of values, mindfulness, and lifestyle. Soc. Indic. Res. 2005, 74, 349-368. [CrossRef]

107. Binder, M.; Blankenberg, A.K. Green lifestyles and subjective well-being: More about self-image than actual behavior? J. Econ. Behav. Organ. 2017, 137, 304-323. [CrossRef]

108. Welsch, H.; Kühling, J. Are pro-environmental consumption choices utility-maximizing? Evidence from subjective well-being data. Ecol. Econ. 2011, 72, 75-87. [CrossRef]

109. Welsch, H.; Kühling, J. How green self-image is related to subjective well-being: Pro-environmental values as a social norm. Ecol. Econ. 2018, 149, 105-119. [CrossRef]

110. Welsch, H.; Kühling, J. Pro-environmental behavior and rational consumer choice: Evidence from surveys of life satisfaction. $J$. Econ. Psychol. 2010, 31, 405-420. [CrossRef]

111. Spolaore, E.; Wacziarg, R. How deep are the roots of economic development? J. Econ. Lit. 2013, 51, 325-369. [CrossRef] 